\title{
Microcystin assimilation and detoxification by Daphnia spp. in two ecosystems of different cyanotoxin concentrations
}

\author{
Adrianna WOJTAL-FRANKIEWICZ, ${ }^{*}$ Joanna BERNASIŃSKA, ${ }^{2}$ Tomasz JURCZAK, ${ }^{1}$ Krzysztof GWOŹDZIŃSKI, ${ }^{2}$ \\ Piotr FRANKIEWICZ, ${ }^{1}$ Marzena WIELANEK ${ }^{3}$ \\ ${ }^{1}$ Department of Applied Ecology, University of Lodz, Banacha 12/16 Str., 90-237 Lodz, Poland; ${ }^{2}$ Department of Molecular \\ Biophysics, University of Lodz, Pomorska 141/143 Str., 90-236 Lodz, Poland; ${ }^{3}$ Department of Plant Physiology and Biochemistry, \\ University of Lodz, Banacha 12/16 Str., 90-237 Lodz, Poland. \\ *Corresponding author: adwoj@biol.uni.lodz.pl
}

\begin{abstract}
Microcystins (MCs), the main group of cyanotoxins, can induce oxidative stress in the cells of aquatic animals. This study evaluated the sensitivity of daphniids - from two ecosystems characterised by different trophic states and habitat levels of cyanobacteria abundance - to microcystin toxicity by analysing oxidative stress parameters and MC detoxification ability. As a study site, we chose the eutrophic Sulejow reservoir, which has regular annual toxic cyanobacterial blooms, and the mesotrophic lake Biate, where low abundances of cyanobacteria have only recently appeared. We found much higher accumulations of MCs in tissues of Daphnia spp. in lake Białe, despite low toxin concentrations in this ecosystem compared with the Sulejow reservoir. Simultaneously, high levels of lipid peroxidation (LPO) and a significant decrease in glutathione (GSH) were observed in daphniid cells in lake Biate, while LPO levels were generally lower and GSH concentration more stable in the Sulejow reservoir. Catalase activity, which reflects more efficient oxidative protection, was always significantly higher in the reservoir than in lake Biate. These results demonstrate that generations of daphniids from the Sulejow reservoir had more effective antioxidant systems protecting them against the accumulation of cyanobacterial toxins; thereby, they are less susceptible to toxic effects than the daphniids from lake Biate. However, the presence of conjugate forms of microcystins (MC-GSH and MC-Cys) in tissues of the studied animals indicated the ability for MC detoxification by daphniids from the Sulejow reservoir and lake Białe. Nevertheless, the high effectiveness of antioxidant systems in daphniids coexisting with cyanobacteria for a long time in the Sulejow reservoir indicates the importance of a selective pressure exerted by toxic cyanobacterial strains that favours the most resistant daphniid genotypes.
\end{abstract}

Key words: glutathione, lipid peroxidation, catalase, conjugates, Daphnia spp., cyanobacteria.

Received: June 2012. Accepted: November 2012.

\section{INTRODUCTION}

Many aquatic ecosystems in Europe, particularly shallow lakes, are characterised by high levels of nutrients due to anthropogenic influences, resulting in intense cyanobacterial blooms. Many cyanobacterial species/ strains are able to produce a wide range of secondary metabolites that are toxic to both animals and plants (Wiegand and Pflugmacher, 2005). One of the most wellknown groups of cyanobacterial toxins are microcystins (MCs) - a group of over 60 variants of cyclic heptapeptide hepatotoxins produced by genera such as Microcystis, Nostoc, Planktothrix (Oscillatoria), Anabaena and Anabaenopsis (Martins and Vasconcelos 2009). The toxic mechanism of MCs is via the specific inhibition of protein phosphatases (PP), types 1 and $2 \mathrm{~A}$, and the generation of oxidative stress, which manifests an increase of lipid peroxidation in animal cells (Goldberg et al., 1995; Bouaïcha and Maatouk, 2004; Wiegand and Pflugmacher, 2005; Amado and Monserrat, 2010). Consequently, cyanobacteria can decrease the population growth, fecundity and survival of aquatic organisms (Smith et al., 2008; Gérard et al., 2009; Martins and Vasconcelos, 2009). Many studies have shown that herbivorous zooplankton species, such as Daphnia, which cannot select and reject inedible algal cells during filtration, are particularly subject to the negative impacts of toxic cyanobacterial strains (e.g. Stangenberg, 1968; Lampert, 1981; Nizan et al., 1986; Fulton and Paerl, 1987; DeMott, 1999; Lürling, 2003). Indeed, the non-selective grazing of Daphnia contributes to the accumulation of cyanobacterial toxins in their tissues. For example, Thorstrup and Christoffersen (1999) showed experimentally that Daphnia magna was able to accumulate up to $24.5 \mu \mathrm{g} \mathrm{MC} \mathrm{g}^{-1}$ dry mass, and Oberhaus et al. (2007) observed even up to $1090 \mu \mathrm{g} \mathrm{MC} \mathrm{g}{ }^{-1}$ dry mass in D. pulicaria individuals consuming small filaments of Planktothrix. In addition to their toxicity, cyanobacterial filaments and colonies are difficult for grazers to ingest due to their large size (e.g. De Bernardi and Giussani, 1990). Furthermore, the absence of sterols and polyunsaturated fatty acids (Martin-Creuzburg et al., 2008) and the 
production of protease inhibitors (Schwarzenberger et al., 2010) render cyanobacteria a poor-quality food for zooplankton. However, although the relative importance of these factors remains poorly recognised, the meta-analysis of laboratory growth experiments has indicated large variations in species-specific responses of zooplankton to the toxicity, morphological properties and nutritional deficiencies of cyanobacteria (Wilson et al., 2006; Tillmanns et al., 2008). In ecological studies, the body length of the zooplankton species is one of the most widespread criteria explaining the differences in the species responses to cyanobacteria. Small-sized cladocerans (Ceriodaphnia spp. or small species of Daphnia) appear to be less affected by a diet of cyanobacteria than large-sized species, so that they are stronger competitors than large species when both groups are exposed to cyanobacterial colonies or filaments (Lampert, 1982; Gliwicz and Lampert, 1990; Guo and Xie, 2006). Nonetheless, various adaptations of herbivore cladocerans to cyanobacteria defences, irrespective of their body length, species or even among different clones of the same species, have been documented in the literature (e.g. DeMott et al., 1991; Repka, 1998). As daphniids regularly coexist with cyanobacteria, they have evolved some behavioural and physiological mechanisms to reduce their exposure to the toxins. For example, daphniids actively avoid cyanobacterial species by migrating (Burns et al., 1989), by reducing the size of the feeding gap in the carapax shell or their filtration rate during algal blooms (Gliwicz and Siedlar, 1980). Nevertheless, the evolution of the phenotypic plasticity of daphniids, which may increase their resistance to toxic cyanobacteria in natural habitats, has only been documented a few times (Hairston et al., 1999, 2001; Sarnelle and Wilson, 2005). Less is also known about the ability of microcystin assimilation or detoxification by the conjugation to glutathione in the tissues of Daphnia spp. Moreover, such studies are mainly performed under laboratory conditions using unnaturally high concentrations of purified microcystins or cultured cyanobacteria. Consequently, the results generally do not reflect the antioxidant defences or toxicity responses of daphniids coexisting with cyanobacteria in the natural environment.

In our study, we chose two ecosystems characterised by different trophic states and different habitat levels of cyanobacterial abundance: the eutrophic Sulejow reservoir, which experiences annual toxic cyanobacterial blooms, and the mesotrophic lake Białe in which low concentrations of cyanobacteria have appeared only recently. We hypothesised that the daphniids from the reservoir, which have coexisted with toxic cyanobacteria for over 30 years, could have developed specific adaptations protecting them against the cyanobacterial toxins during blooms. In contrast, we assumed that the daphniids from lake Białe would be more sensitive to microcystins due to a lack of previous selective pressures for developing resistance to cyanobacterial toxicity. Thus, the aim of this study was to evaluate the sensitivity of the daphniids from these two ecosystems to microcystin toxicity under natural conditions by analysing oxidative stress parameters and the ability of MCs detoxification.

\section{METHODS}

Sulejow reservoir is a 38-year-old, lowland dam reservoir situated on $\mathrm{km} 138.9$ of the Pilica river (the Vistula river catchment) in Central Poland ( $51^{\circ} 22^{\prime}-51^{\circ} 28^{\prime} \mathrm{N}$ and $19^{\circ} 51^{\prime}-20^{\circ} 01^{\prime} \mathrm{E}$ ) (Fig. 1). Its maximum length is $15.5 \mathrm{~km}$, and its maximum width is $2.1 \mathrm{~km}$. At its maximum capacity $\left(75 \times 10^{6} \mathrm{~m}^{3}\right)$, the reservoir covers $1980 \mathrm{ha}$, with a mean depth of $3.3 \mathrm{~m}$ and a maximum depth of $11 \mathrm{~m}$. The mean water retention time in the reservoir is 30 days (Wagner et al., 2009). The reservoir subcatchment is mainly covered by agricultural land (50\% arable land, $13 \%$ meadows and pastures, $1 \%$ orchards) and forests (31\%). The length of the shoreline is approximately $54 \mathrm{~km}$. The Sulejow reservoir is a eutrophic ecosystem: the mean total phosphorus concentration during the years 1997-2006 was approximately $0.137 \mathrm{mg} \mathrm{dm}^{-3}$, ranging from 0.013 to 1.053 $\mathrm{mg} \mathrm{dm}{ }^{-3}$ (Wagner et al., 2009). The dominant species of bloom-forming cyanobacteria is Microcystis aeruginosa (Kutzing), which produces microcystin-LR, -YR and -RR (Tarczyńska et al., 2001; Jurczak et al., 2005). During the period 1996-2006, the average annual cyanobacterial biomass varied between $1.8 \mathrm{mg} \mathrm{dm}^{-3}$ and $13.4 \mathrm{mg} \mathrm{dm}^{-3}$, with a maximum value of $180 \mathrm{mg} \mathrm{dm}^{-3}$ in 1999 in the pelagic zone of the reservoir (Wagner et al., 2009). The adult fish stock was mostly composed of roach (Rutilus rutilus L.), common bream (Abramis brama L.), white bream (Blicca bjoerkna L.), pikeperch (Stizostedion lucioperca L.), perch (Perca fluviatilis L.), bleak (Alburnus alburnus L.) and asp (Aspius aspius L.), while perch and roach dominate the juvenile fish community.

Lake Białe is situated in Płock basin on Gostynin lakeland (52 $29^{\prime} 32^{\prime \prime} \mathrm{N}$ and $\left.19^{\circ} 30^{\prime} 49^{\prime \prime} \mathrm{E}\right)$ (Fig. 1). It is a postglacial ribbon lake that covers 150 ha with a capacity of $14,885 \mathrm{~m}^{3}$. The length of lake Białe is $3 \mathrm{~km}$, and its width is $0.8 \mathrm{~km}$. The mean depth of this lake is $9.9 \mathrm{~m}$, and the maximum depth is $31 \mathrm{~m}$ (Choiński, 2006). During summer, thermal and aerobic stratification is observed. The lake's subcatchment is mainly covered by meadows, and there are virtually no forests. Lake Białe is characterised by good water quality (mesotrophic): the total phosphorus concentration during the years 2007-2009 ranged from 0.012 to $0.330 \mathrm{mg} \mathrm{dm}^{-3}$ (Provincial Inspectorate for Environmental Protection, 2010). The presence of cyanobacteria in lake Białe was not detected until 2010 (Provincial Inspectorate for Environmental Protection, 2010). The fish stock was mostly composed of common bream (Abramis brama L.), roach (Rutilus rutilus L.), perch 
(Perca fluviatilis L.), pike (Esox lucius L.) and eel (Anquila anquila $\mathrm{L}$.).

In 2010, the fieldwork was conducted three times: before, during, and after cyanobacterial (beginning of June, August and October, respectively). The terms were established according to the results of the scientific monitoring of Sulejow reservoir, which was performed weekly from April to October by the Department of Applied Ecology University of Lodz, and that of lake Biale, which was performed eight times per year through the National Monitoring of the Environment by the Provincial Inspectorate for Environmental Protection in Warsaw (Provincial Inspectorate for Environmental Protection, 2010). However, in 2011, we increased the frequency of the sampling to four times due to high intensity of cyanobacterial blooms in Sulejow reservoir. Thus, in 2010, the sampling was conducted on $1^{\text {st }}$ June, $17^{\text {th }}$ August and $6^{\text {th }}$ October in Sulejow reservoir and on $2^{\text {nd }}$ June, $19^{\text {th }}$ August and $13^{\text {th }}$ October in lake Białe. In 2011, the sampling was performed on $3^{\text {rd }}$ June, $12^{\text {th }}$ July, $26^{\text {th }}$ August and $16^{\text {th }}$ September in Sulejow reservoir and on June $7^{\text {th }}$, July $13^{\text {th }}$, August $24^{\text {th }}$ and September $14^{\text {th }}$ in lake Białe.

\section{Physical and chemical water analyses}

Water temperature $\left({ }^{\circ} \mathrm{C}\right)$, total dissolved oxygen (TDO, $\left.\mathrm{mg} \mathrm{L}^{-1}\right), \mathrm{pH}$ and conductivity $\left(\mu \mathrm{S} \mathrm{cm}^{-1}\right)$ were measured between 10:00 and 11:30 am in both study sites using YSI Professional Plus multisensors (YSI Inc., Yellow Springs, $\mathrm{OH}, \mathrm{USA}$ ). These parameters were measured along the established transects in the off-shore part of Sulejow reservoir and lake Białe (Fig. 1) at 0.5-1.0 $\mathrm{m}$ depth. Water for the chemical analyses (1 L of non-filtered water) was collected from the same transect locations and depths in both ecosystems. In a laboratory, the ions of phosphate, nitrate and ammonium were analysed on a Dionex-1000, which consists of two ion chromatography (ICs), separated for anions and cations. Each IC (ICS-1000; Dionex Corporation, Waltham, MA, USA) consists of a pump, eluent, guard columns (CG18 for cations and AG18 for anions), analytical columns (IonPac CS18 for cations, IonPac AS18 for anions) and an electrolytic suppressor (CSRS-ULTRA II cation electrolytic suppressor and ASRS-ULTRA II anion electrolytic suppressor) to stabilise the baseline. The ions were analysed by using $16-\mathrm{mM}$ methanesulphonic acid (Fluka, St. Gallen, Switzerland) for the cation analysis and

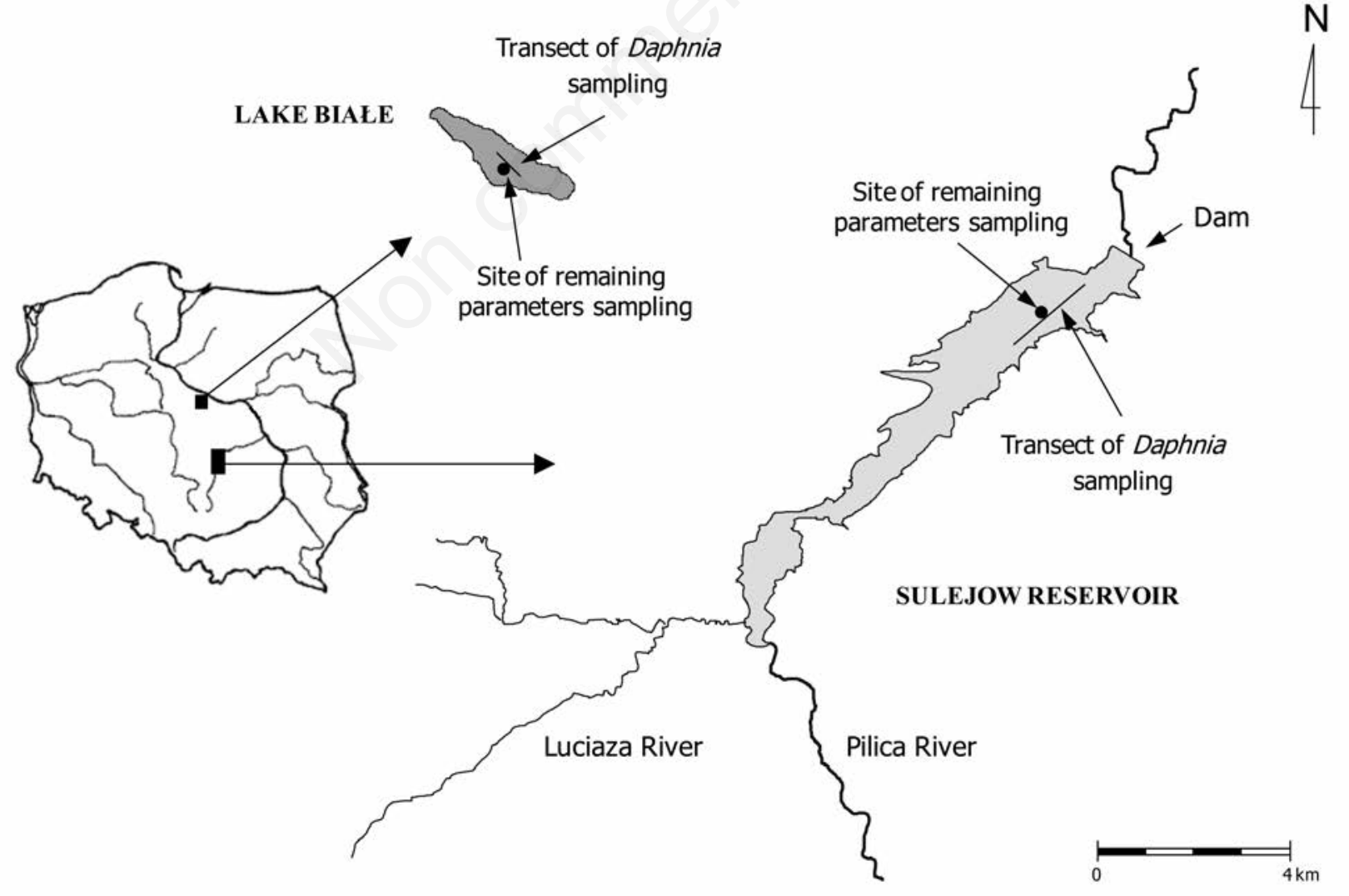

Fig. 1. Study areas: lake Białe and the Sulejow reservoir, with the sites of all parameters sampling. 
a mixture of $4.5-\mathrm{mM}$ sodium carbonate and $1.4-\mathrm{mM}$ sodium bicarbonate for the anion system prepared from the AS22 Eluent Concentrate (Dionex Corporation). Both ICs were operated under isocratic elution conditions at $30^{\circ} \mathrm{C}$ and a flow rate of $1 \mathrm{~mL} / \mathrm{min}$. The cation measurements were performed using a $25 \mu \mathrm{L}$ injection loop, while the anion ones were performed using a $450 \mu \mathrm{L}$ injection loop. Combined standards were used for ion identification (Seven Anion Standard II, Six Cation Standard; Dionex Corporation).

Total phosphorus (TP) was measured using the ascorbic acid method according to Golterman et al. (1978). Total nitrogen (TN) was analysed using the persulphate digestion method (method no. 10071; Hach, 1997).

\section{Plankton collection, preparation and identification}

Zooplankton samples were collected from a $0.5-\mathrm{m}$ depth using a 64- $\mu \mathrm{m}$ mesh on the same transects where physical and chemical parameters were measured, both in Sulejow reservoir and in lake Białe (Fig. 1). A net with a $0.25 \mathrm{~m}$ diameter was dragged by a boat for $10 \mathrm{~min}$ with a speed of $0.5 \mathrm{~m} \mathrm{~s}^{-1}$, which resulted in sieving approximately $15,000 \mathrm{~L}$ of water. During the most intensive cyanobacterial blooms in Sulejow reservoir (on August $17^{\text {th }} 2010$ and July $12^{\text {th }} 2011$ ), zooplankton was collected using a 5-L sampler (with many repetitions) at a 4-m depth due to the high concentration of Microcystis aeruginosa in the surface water layer. In the laboratory, samples were put into the 2-L glass separator and washed by water many times to separate zooplankton from phytoplankton. Individuals of Daphnia spp. were then selected under a Nikon 102 microscope (magnification of 40-60×) with a pipette and placed into a vessel with distilled water. Subsequently, Daphnia spp. individuals were gravitationally filtrated (without using a pump) on Whatman GF/C filter paper (Whatman, Maidstone, UK). The animals were gently removed from the filters with a needle and separated into nine Eppendorf test tubes (approximately 500-600 daphniids per each tube) (Eppendorf AG, Hamburg, Germany). The test tubes were frozen at $-70^{\circ} \mathrm{C}$ before the chemical analyses.

To identify the zooplankton species (qualitative analyses), $35 \mathrm{~L}^{-1}$ of water was filtered using a $64-\mu \mathrm{m}$ mesh net, and the samples were concentrated to $10 \mathrm{~mL}$ and preserved in a 4\% Lugol's solution. Zooplankton taxa were distinguished under a Nikon 115 microscope (magnification of 100-200×) (Nikon Corp. Shinjuku, Japan). The Daphnia species collected were morphologically identified following Benzie (2005).

Phytoplankton species composition (qualitative analyses) was examined in $10 \mathrm{~L}^{-1}$ water samples taken on each sampling occasion. The water samples for phytoplankton estimation were preserved in a Lugol's solution and sedimented in the laboratory. Algae were counted using a
Fusch-Rosenthal counting cell. At least 400 cells or filaments were counted to reduce the error to less than $10 \%$ $(\mathrm{P}=0.05)$. The collected material was morphologically analysed according to Starmach (1966), Komarek (1991), Komarek and Anagnostidis (1999) and Krammer and Lange-Bertalot (1986, 1988, 1991a, 1991b).

\section{Chlorophyll $a$ concentration}

The concentration of chlorophyll $a\left(\mu \mathrm{g} \mathrm{L}^{-1}\right)$ was measured immediately after sampling in a 1-L integrated water sample using a bbe Algae Online Analyser (AOA) (Version 1.5 E1, AOA, bbe-Moldaenke, Kiel, Germany), and the chlorophyll $a$ was then classified into the four main groups of algae (green algae, cyanobacteria, diatoms and cryptophytes). The measurement principle of the bbe AOA is based on the determination of the fluorescence spectrum and the fluorescence kinetics of the algae. Each type of alga has a characteristic fluorescence that is reflected by the colour and brightness of the excitation light. To differentiate between the different classes of algae, a spectrum of the mixture was recorded, and a statistical arithmetic procedure was used to determine the different algae classes within the sample. This method is recognised as a reliable on-line analysis for chlorophyll $a$ measurements (Cagnard et al., 2006) and a useful tool for monitoring the phytoplankton community composition, especially as an early warning system for the detection of harmful algal blooms (Richardson et al., 2010). The AOA fluorometer was tested as an early warning method for cyanobacterial blooms in Sulejow reservoir. The results of these studies demonstrated a significant positive correlation $(\mathrm{r}=0.68, \mathrm{n}=46, \mathrm{P}<0.05)$ between cyanobacterial biovolume, as determined by cell counts, and cyanobacterial chlorophyll $a$, as measured by the AOA (Izydorczyk et al., 2009).

\section{Microcystin concentrations - sample preparation and analyses}

Samples of water containing cyanobacteria were stored in dark glass bottles and transported to the laboratory for analyses immediately after sampling. We used 1L samples of water from both ecosystems and an additional 1-L integrated samples from 15,000 L of water from lake Biake due to extremely low concentrations of cyanobacteria in this lake.

The microcystins were analysed in two fractions: dissolved in water (extracellular) and a cell-bound form in suspended matter (intracellular). For the analysis of microcystins in suspended matter, the water samples were filtered on Whatman GF/C filter paper (Whatman) and dried to estimate the dry biomass of cyanobacteria. The filters were then stored at $-20^{\circ} \mathrm{C}$ until required. Microcystins in the suspended material were extracted in $75 \%$ aqueous methanol. The samples were sonicated for $30 \mathrm{~s}$ 
in a Misonix ultrasonicator (Misonix Inc., Farmingdale, NY, USA) equipped with an ultrasonic probe (100 W, 19 $\mathrm{mm}$ diameter with spike) and a liquid processor XL. The extracts were then centrifuged twice at $11,000 \times g$ for 10 min at $4^{\circ} \mathrm{C}$ in an Eppendorf 5804 centrifuge (Eppendorf AG). The supernatants were collected and evaporated in a SC110A Speedvac ${ }^{\circledR}$ Plus (ThermoSavant, Holbrook, NY, USA). Before the high performance liquid chromatography (HPLC) analysis, the samples were redissolved in $1 \mathrm{~mL}$ of $75 \%$ aqueous methanol and filtered through a Gelman GHP Acrodisc 13-mm syringe filter with a $0.45-\mathrm{mm}$ GHP membrane and a minispike outlet (Pall-Gelman Corp., East Hills, NY, USA).

For dissolved microcystins, 1-L samples of filtered water were concentrated in Baker $\mathrm{C}_{18}$ solid phase extraction (SPE) cartridges (sorbent mass: $500 \mathrm{mg}$ ) (J.T. Baker, Deventer, The Netherlands). The microcystins were eluted from the $\mathrm{C}_{18}$ cartridges with $3 \mathrm{~mL}$ of $90 \%$ aqueous methanol containing $0.1 \%$ trifluoroacetic acid (TFA). The eluates were then evaporated to dryness, and the samples were redissolved in $1 \mathrm{~mL}$ of $75 \%$ aqueous methanol before HPLC analysis.

The samples were analysed using an Agilent 1100 series (Agilent Technologies, Waldbronn, Germany) HPLC comprising a quaternary pump, an autosampler, a thermostated column compartment and a diode-array detector. Chromatographic separation was achieved on a Merck Purospher Star RP-18e column $(55 \times 4 \mathrm{~mm} ; 3 \mathrm{~mm})$ with a $\mathrm{C}_{18}$ guard column $(4 \times 4 \mathrm{~mm})$. A determination of microcystins by HPLC-diode-array detection (HPLC-DAD) was performed using a gradient mobile phase of $\mathrm{H}_{2} \mathrm{O}+0.05 \%$ TFA (eluent A) and acetonitrile (ACN) $+0.05 \%$ TFA (eluent B) and diode-array detection at 200-300 $\mathrm{nm}$. The linear gradient conditions were as follows: $25 \% \mathrm{~B}$ at $0.0 \mathrm{~min}, 70 \%$ $\mathrm{B}$ at $5.0 \mathrm{~min}, 70 \% \mathrm{~B}$ at $6.0 \mathrm{~min}$ and $25 \% \mathrm{~B}$ at $6.1 \mathrm{~min}$. The sample volume was $20 \mathrm{~mL}$, the flow rate was $1 \mathrm{~mL} \mathrm{~min}^{-1}$ and the column temperature $40^{\circ} \mathrm{C}$. The microcystins in the cyanobacterial extracts were identified using the microcystin standards MC-LR, MC-RR and MC-YR with their characteristic absorption spectra and retention times. Microcystins MC-LR, MC-RR and MC-YR are the main microcystins detected in Polish freshwaters (Jurczak et al., 2004). Three microcystin standards from seven commercially available products from Calbiochem (Calbiochem, La Jolla, CA, USA) were used.

\section{Determination of microcystin concentrations in tissues of daphniids}

Daphnia spp. soft tissues were placed at $20 \% \mathrm{w} / \mathrm{v}$ in $75 \%$ aqueous methanol and homogenised on an ice bath at $2000 \mathrm{rpm}$ for $2 \mathrm{~min}$. The suspension was centrifuged at $13,000 \times \mathrm{g}$ for $10 \mathrm{~min}\left(4^{\circ} \mathrm{C}\right)$. The precipitates were washed with $75 \%$ aqueous methanol, sonicated for $15 \mathrm{~s}$ and centrifuged again at $13,000 \times g$ for $10 \mathrm{~min}\left(4^{\circ} \mathrm{C}\right)$. This step was repeated twice, and after each centrifugation, the supernatants were collected and the whole volume was used for a further estimation of microcystin concentrations. The samples were then sonicated for $30 \mathrm{~s}$, centrifuged and evaporated to dryness. The samples were then reconstituted in $75 \%$ aqueous methanol and analysed by HPLC according to the method described above. Using the applied method, the microcystin recovery rate from daphniids is estimated to be $96 \%$ (Ibelings et al., 2005).

\section{Determination of thiobarbituric reactive substances}

Daphnia spp. individuals (wet mass 0.06-0.16 g) were placed at a $10 \% \mathrm{w} / \mathrm{v}$ ratio in a $100-\mathrm{mM}$ sodium phosphate buffer, $\mathrm{pH}$ 7.4, with $100 \mathrm{mM} \mathrm{KCl}$ and $1 \mathrm{mM}$ ethylenediaminetetraacetic acid (EDTA) on ice.

Homogenisation was performed on ice at $2000 \mathrm{rpm}$ for $2 \mathrm{~min}$, and the homogenates were then centrifuged at $10,000 \times g$ for $10 \mathrm{~min}\left(4^{\circ} \mathrm{C}\right)$. The supernatants were immediately used for a cellular lipid peroxidation (LPO) estimation. Lipid peroxidation was measured using a thiobarbituric acid reactive substances (TBARS) assay (Stocks and Dormandy, 1971) with modifications (RiceEvans et al., 1991). The concentration of thiobarbituric acid reactive substances is an index of lipid peroxidation and oxidative stress. The assay was monitored for the appearance of conjugated complexes of thiobarbituric acid, mainly malondialdehyde (MDA), which is the end product of LPO at $532 \mathrm{~nm}$. The MDA levels were calculated using the MDA extinction coefficient $156 \mathrm{mmol}^{-1} \mathrm{~cm}^{-1}$ and expressed as nanomoles per milligram protein (nmol/mg protein).

\section{Determination of glutathione content}

The soft tissues of Daphnia spp. individuals were placed at a $10 \% \mathrm{w} / \mathrm{v}$ ratio in a homogenisation buffer [154 $\mathrm{mM} \mathrm{KCl}, 5 \mathrm{mM}$ diethylenetriaminepentaacetic acid (DTPA) and $0.1 \mathrm{M}$ potassium phosphate buffer, $\mathrm{pH}$ 6.8] and homogenised on ice at $2000 \mathrm{rpm}$ for $2 \mathrm{~min}$. An aliquot was removed for protein determination using the Lowry method (Lowry et al., 1951). The remainder of the homogenate was mixed with a cold acid buffer containing $40 \mathrm{mM} \mathrm{HCl}, 10 \mathrm{mM}$ DTPA, $20 \mathrm{mM}$ ascorbic acid and $10 \%$ trichloroacetic acid (TCA) at a ratio of 1:1. The suspension was centrifuged at $13,000 \times g$ for $10 \mathrm{~min}\left(4^{\circ} \mathrm{C}\right)$. The supernatants were immediately used for further determination of the glutathione (GSH) content.

The GSH was estimated according to the fluorescence assay of Senft et al. (2000) using o-phthalaldehyde (OPA). In this method, OPA, which has a low fluorescence background, reacts only with GSH to generate a strong fluorescence so that GSH can be specifically quantified. The OPA-derived fluorescence was measured at $365 \mathrm{~nm}$ excitation and $430 \mathrm{~nm}$ emission. 
The glutathione concentration was calculated using the calibration curve for different concentrations of reduced gluthatione, as a standard, and expressed as nanomoles per milligram protein ( $\mathrm{nmol} / \mathrm{mg}$ protein).

\section{Determination of catalase activity}

Daphnia spp. individuals (wet mass 0.06-0.16 g) were placed at a $10 \% \mathrm{w} / \mathrm{v}$ ratio in $100 \mathrm{mM}$ sodium phosphate buffer, $\mathrm{pH}$ 7.4, with $100 \mathrm{mM} \mathrm{KCl}$ and $1 \mathrm{mM}$ EDTA on ice. Homogenisation was performed on ice at $2000 \mathrm{rpm}$ for 2 min, and the homogenates were then centrifuged at $10,000 \times g$ for $10 \mathrm{~min}\left(4^{\circ} \mathrm{C}\right)$. The supernatants were immediately used for catalase activity determination. The activity of catalase (CAT) was measured spectrophotometrically according to Aebi (1984). The method is based on the decomposition of hydrogen peroxide, which is indicated by decrease in absorbance at $240 \mathrm{~nm}$. The assay mixture consisted of homogenate, $50 \mathrm{mM}$ potassium phosphate buffer $\mathrm{pH} 7.0$ and $0,1 \%$ hydrogen peroxide in the final volume of $3 \mathrm{~mL}$. The results of this enzymatic assay were reported in units of CAT activity per milligram of protein (U/mg protein), where $1 \mathrm{U}$ of CAT is defined as the amount of enzyme decomposing $1 \mu \mathrm{mol}$ of $\mathrm{H}_{2} \mathrm{O}_{2}$ per second.

\section{Determination of protein concentration}

The protein concentration was evaluated using the spectrophotometric method (Lowry et al., 1951) with Folin's reagent. The amount of protein in each sample was estimated using the calibration curve for different concentrations of bovine albumin as a standard.

\section{Determination of conjugates presence in tissues of daphniids}

Liquid chromatography with mass detection (LC/MS) was carried out using the API LC/MS/MS system (Applera, Foster City, CA, USA) with an electrospray ionisation (ESI) source equipped with a Dionex HPLC system containing a quaternary pump, autosampler, thermostated column compartment, vacuum degasser and diode array detector. The compounds were separated on an RP column (Hypersil GOLD, 2.1 i.d. $\times 150 \mathrm{~mm}, 3.5 \mu \mathrm{m}$ ) at $40^{\circ} \mathrm{C}$ using a gradient elution of water (A) and acetonitrile (B), both with $0.5 \%$ TFA. The elution profile with a flow rate of 0.2

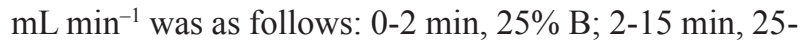
$70 \% \mathrm{~B}$; $15-18 \mathrm{~min}, 70 \% \mathrm{~B}$; $18-20 \mathrm{~min}, 75-25 \% \mathrm{~B} ; 20-23$ $\min , 25 \% \mathrm{~B}$. The effluent was transferred on-line to the ESI-MS system without splitting. A detection was performed in positive ion modes with the condition set as follows: drying gas $\left(\mathrm{N}_{2}\right) 11.0 \mathrm{~L} \mathrm{~min}^{-1}$, temperature $350^{\circ} \mathrm{C}$, nitrogen nebuliser pressure $40 \mathrm{psi}$, capillary voltage 4.5 $\mathrm{kW}$, a detector gain of $1600 \mathrm{~V}$, fragmentation voltage 130 $\mathrm{V}$ and full scan range from 300 to $1400 \mathrm{~m} \mathrm{z}^{-1}$.

The MC-LR-GSH and MC-RR-GSH conjugates, as standards for HPLC-ESI-MS/MS analyses, were prepared in vitro using microcystin standards from Calbiochem. The samples of microcystin were incubated with excess glutathione (1:10) in phosphate buffer $\mathrm{pH} 7.4$ in the presence of glutathione S-transferase for $12 \mathrm{~h}$ at room temperature, dried in vacuum at room temperature, extracted with chloroform and evaporated to dryness. The residue was dissolved in $75 \%$ aqueous methanol for analysis by HPLC.

\section{Statistical methods}

All of the statistical analyses were conducted in Statistica 9.0 (StatSoft Inc., Tulsa, OK, USA). To test for the effects of the season and ecosystem type on the parameters analysed in 2010, we used a two-way ANOVA with the seasons and lakes as categorical factors and the oxidative stress parameters in Daphnia spp. tissues as the dependent factors. For testing the same effects in 2011, a one-way ANOVA was applied due to incomplete design (cf. the lack of daphniids in July samples from lake Białe).

\section{RESULTS}

\section{Physical and chemical water analyses}

The analyses of the physical parameters of water did not show any major differences between the two ecosystems studied in 2010 and 2011. Both temperature and $\mathrm{pH}$ values were similar in Sulejow reservoir and in lake Białe (Tab. 1). The oxygen concentration was higher in Sulejow reservoir than in lake Białe in August 2010 and 2011 and in September 2011. This finding was most likely the result of intensive photosynthesis occurring when conducting measurements during the cyanobacterial blooms. The conductivity changed seasonally in both the ecosystems (Tab. 1).

The values of the measured chemical parameters were different between the lakes studied (Tab. 1), which reflected differences in their trophic state. It is worth noticing that the phosphate ion concentration was one order of magnitude higher in Sulejow reservoir than in lake Białe in 2010 and 2011, except during the period of the most intensive blooms in the reservoir (August 2010 and July 2011).

\section{Identification of the plankton species community}

Three species of Cladocera from the Daphnia longispina group: D. longispina (O.F. Müller, 1776), D. galeata Sars, 1864 and D. hyalina Leydig, 1860 were identified in the samples from Sulejow reservoir in 2010 and 2011. During these years, the dominant species of Cladocera in lake Białe was Daphnia cucullata Sars, 1862. During spring (June) the numerical share of D. $\mathrm{Cu}$ cullata in the samples from the lake was $90 \%$, whereas the numerical share of D. galeata was only $10 \%$. In August, D. cucullata was the only species of the Daphnia 
genus identified in lake Białe. In September and October, $D$. longispina was also identified, but its numerical share in the samples was only $5 \%$, whereas $D$. cucullata was $95 \%$. In zooplankton samples taken from lake Białe in July 2011, Daphnia spp. individuals were not found.

The phytoplankton species composition changed seasonally in both ecosystems, but was similar in both years. The dominant genera of the phytoplankton identified during spring in Sulejow reservoir were as follows: Euglena sp. (Euglenophyta), Fragilaria sp., Navicula sp. (Bacillariophyceae) and Closterium sp. (Chlorophyta). In summer, a cyanobacteria bloom was observed. We identified Microcystis aeruginosa, Aphanizomenon flos-aquaae (Cyanobacteria), Asterionella formosa (Hassall) (Bacillariophyceae), Scenedesmus sp. (Chlorophyta) and all the genera that were present in spring. In September and October, M. aeruginosa, Euglena sp., Fragilaria sp., Navicula sp., Asterionella formosa, Melosira varians (C. Agardh), Nitzschia sp. (Bacillariophyceae) and Crucigenia rectangularis [(Nägeli) Gay] (Chlorophyta) were still detected in Sulejow reservoir.

We identified Euglena sp., Asterionella formosa, Cyclotella sp., Tabelaria floculosa [(Roth) Kützing] (Bacil- lariophyceae), Coleastrum sp. (Chlorophyta) and Dinobryon sp. (Heterokontophyta) during spring (June) in lake Białe. In summer, the dominant phytoplankton species were Asterionella formosa, Crucigenia rectangularis (Chlorophyta) and Gloeocapsa sp. (Cyanobacteria). In 2010 and 2011, we also found a small quantity of Microcystis aeruginosa (two to four cells $\mathrm{L}^{-1}$ ), although this potentially toxic species of cyanobacteria did not previously appear in lake Białe. The most numerous species or genera of phytoplankton in lake Białe during autumn (October) were Euglena sp., Achnanthes minutissima (Kützing), Asterionella formosa, Cyclotella sp., Fragilaria sp. and Ceratium hirundinella (Dinoflagellates).

\section{Chlorophyll $a$ concentration}

Compared to lake Biale, the chlorophyll $a$ concentrations in Sulejow reservoir were three times higher in July 2010 and more than five times higher in August 2010 (Fig. 2a). In June, the total chlorophyll $a$ concentrations in Sulejow reservoir reached $15.77 \mu \mathrm{g} \mathrm{L} \mathrm{L}^{-1}$, while in lake Białe, they were $4.13 \mu \mathrm{g} \mathrm{L} \mathrm{L}^{-1}$. During summer (August), chlorophyll $a$ concentrations reached $32.63 \mu \mathrm{g} \mathrm{L}^{-1}$ in Sulejow

Tab. 1. Physical and chemical parameters characterising Sulejow reservoir and lake Białe in 2010 and 2011. For the ions and the total forms of phosphorus and nitrogen, the average values from three replicates $\pm \mathrm{SD}$ are presented.

\begin{tabular}{|c|c|c|c|c|c|c|}
\hline & \multicolumn{2}{|c|}{ June 2010} & \multicolumn{2}{|c|}{ August 2010} & \multicolumn{2}{|c|}{ October 2010} \\
\hline & Sulejow r. & L. Białe & Sulejow r. & L. Białe & Sulejow r. & L. Białe \\
\hline \multicolumn{7}{|l|}{ Physical parameters } \\
\hline Temperature $\left({ }^{\circ} \mathrm{C}\right)$ & 17.60 & 17.2 & 24.50 & 22.70 & 11.50 & 11.50 \\
\hline Oxygen con. (mg L $\left.{ }^{-1}\right)$ & 5.67 & 6.83 & 9.32 & 7.50 & 6.86 & 9.27 \\
\hline $\mathrm{pH}$ & 7.48 & 7.45 & 8.86 & 8.30 & 7.72 & 7.46 \\
\hline Conductivity $\left(\mu \mathrm{S} \mathrm{cm}^{-1}\right)$ & 276 & 281 & 300 & 318 & 357 & 336 \\
\hline \multicolumn{7}{|l|}{ Ions (mg L $\left.{ }^{-1}\right)$} \\
\hline Phosphate & $0.040_{( \pm 0.01)}$ & $0.004_{( \pm 0.00)}$ & $0.003_{( \pm 0.00)}$ & $0.004_{( \pm 0.00)}$ & $0.039_{( \pm 0.00)}$ & $0.005_{( \pm 0.00)}$ \\
\hline Nitrate & $2.370_{( \pm 0.17)}$ & $0.498_{( \pm 0.05)}$ & $0.284_{( \pm 0.00)}$ & $0.038_{( \pm 0.20)}$ & $4.135_{( \pm 0.14)}$ & $0.048_{( \pm 0.01)}$ \\
\hline Ammonium & $0.065_{( \pm 0.01)}$ & $0.006_{( \pm 0.00)}$ & $0.011_{( \pm 0.01)}$ & $0.013_{( \pm 0.01)}$ & $0.011_{( \pm 0.01)}$ & $0.013_{( \pm 0.01)}$ \\
\hline Total phosph. (mg L $\left.{ }^{-1}\right)$ & $0.150_{( \pm 0.04)}$ & $0.081_{( \pm 0.01)}$ & $0.246_{( \pm 0.01)}$ & $0.084_{( \pm 0.01)}$ & $0.144_{( \pm 0.01)}$ & $0.068_{( \pm 0.01)}$ \\
\hline Total nitrogen $\left(\mathrm{mg} \mathrm{L}^{-1}\right)$ & $1.900_{( \pm 0.07)}$ & $1.000_{( \pm 0.02)}$ & $2.400_{( \pm 0.05)}$ & $1.700_{( \pm 0.03)}$ & $5.500_{( \pm 0.11)}$ & $0.150_{( \pm 0.02)}$ \\
\hline
\end{tabular}

\begin{tabular}{|c|c|c|c|c|c|c|c|c|}
\hline & \multicolumn{2}{|c|}{ June 2011} & \multicolumn{2}{|c|}{ July 2011} & \multicolumn{2}{|c|}{ August 2011} & \multicolumn{2}{|c|}{ September 2011} \\
\hline & Sulejow r. & L. Białe & Sulejow r. & L. Białe & Sulejow r. & L. Białe & Sulejow r. & L. Białe \\
\hline \multicolumn{9}{|l|}{ Physical parameters } \\
\hline Temperature $\left({ }^{\circ} \mathrm{C}\right)$ & 21.60 & 23 & 21.7 & 22.50 & 22.50 & 21.60 & 18.20 & 18.80 \\
\hline Oxygen con. $\left(\mathrm{mg} \mathrm{L}^{-1}\right)$ & 9.04 & 10.3 & 9.55 & 11.35 & 11.56 & 8.41 & 10.84 & 8.98 \\
\hline $\mathrm{pH}$ & 8.31 & 8.94 & 9.34 & 9.15 & 9.99 & 9.4 & 9.25 & 8.87 \\
\hline Conductivity $\left(\mu \mathrm{S} \mathrm{cm}^{-1}\right)$ & 344 & 295 & 308 & 309 & 298 & 306 & 298 & 313 \\
\hline \multicolumn{9}{|l|}{ Ions $\left(\mathrm{mg} \mathrm{L}^{-1}\right)$} \\
\hline Phosphate & $0.050_{( \pm 0.01)}$ & $0.003_{( \pm 0.00)}$ & $0.003_{( \pm 0.01)}$ & $0.002_{( \pm 0.00)}$ & $0.010_{( \pm 0.00)}$ & $0.002_{( \pm 0.01)}$ & $0.010_{( \pm 0.00)}$ & $0.004_{( \pm 0.01)}$ \\
\hline Nitrate & 2.510 & $0.040_{( \pm 0.01)}$ & $0.790_{( \pm 0.06)}$ & $0.052_{( \pm 0.00)}$ & 0.480 & $0.051_{( \pm 0.00)}$ & 0.083 & $0.111_{( \pm 0.01)}$ \\
\hline Ammonium & $0.075_{( \pm 0.01)}$ & $0.041_{( \pm 0.00)}$ & $0.154_{( \pm 0.01)}$ & $0.052_{( \pm 0.00)}$ & $0.051_{( \pm 0.01)}$ & $0.023_{( \pm 0.00)}$ & $0.021_{( \pm 0.00)}$ & $0.063_{( \pm 0.01)}$ \\
\hline Total phosph. (mg L $\left.{ }^{-1}\right)$ & $0.071_{( \pm 0.01)}$ & $0.038_{( \pm 0.01)}$ & $0.079_{( \pm 0.01)}$ & $0.045_{( \pm 0.01)}$ & $0.331_{( \pm 0.03)}$ & $0.123_{( \pm 0.03)}$ & $0.199_{( \pm 0.01)}$ & $0.049_{( \pm 0.01)}$ \\
\hline Total nitrogen $\left(\mathrm{mg} \mathrm{L}^{-1}\right)$ & $1.250_{( \pm 0.04)}$ & $0.500_{( \pm 0.03)}$ & $0.800_{( \pm 0.02)}$ & $0.300_{( \pm 0.01)}$ & $3.250_{( \pm 0.08)}$ & $2.900_{( \pm 0.15)}$ & $4.800_{( \pm 0.13)}$ & $3.100_{( \pm 0.07)}$ \\
\hline
\end{tabular}

Sulejow r., Sulejow reservoir; L. Białe, lake Białe; Oxygen con., oxygen concentration; Total phosph., total phosphorus. 
reservoir, and the cyanobacterial share was $25.14 \mu \mathrm{g} \mathrm{L}^{-1}$. In lake Białe, the total concentration of chlorophyll $a$ in August was $6.83 \mu \mathrm{g} \mathrm{L}^{-1}$. In October, chlorophyll $a$ concentrations were comparable in both lakes studied and amounted to $3.17 \mu \mathrm{g} \mathrm{L}^{-1}$ in Sulejow reservoir (including $0.84 \mu \mathrm{g} \mathrm{L}^{-1}$ of $M$. aeruginosa) and $2.45 \mu \mathrm{g} \mathrm{L}^{-1}$ in lake Białe.

In 2011, chlorophyll $a$ concentrations were still much higher in Sulejow reservoir than in lake Białe (Fig. 2b). The differences were especially considerable in July, when the massive cyanobacterial blooms appeared in the reservoir. During this period, chlorophyll $a$ concentration reached $115.18 \mu \mathrm{g} \mathrm{L}^{-1}$ (cyanobacterial share was 100\%), while in lake Białe, it was only $4.93 \mu \mathrm{g} \mathrm{L}^{-1}$. In August, total chlorophyll $a$ concentrations were $12.59 \mu \mathrm{g} \mathrm{L}^{-1}(7.07$ $\mu \mathrm{g} \mathrm{L}^{-1}$ of cyanobacteria) in Sulejow reservoir and $6.58 \mu \mathrm{g}$ $\mathrm{L}^{-1}$ in lake Białe. In September, total chlorophyll $a$ reached $5.87 \mu \mathrm{g} \mathrm{L}^{-1}$ in lake Białe and $26.12 \mu \mathrm{g} \mathrm{L}^{-1}$ (cyanobacterial share was $18.70 \mu \mathrm{g} \mathrm{L}^{-1}$ ) in the reservoir.

It is worth mentioning that while the fluorometer measurements did not detect the presence of cyanobacteria in lake Białe in summer 2010 or 2011, we did find cyanobacteria in the microscopic analysis. This incompatibility resulted from the extremely low density of $M$. aeruginiosa cells (two to four cells in $1 \mathrm{~L}$ ) and, thus, the low probability of drawing their cells into the measuring chamber of the AOA. We assumed that the concentrations of cyanobacteria in lake Białe were under the detection limit of AOA $(<0.05$ $\mu \mathrm{g} \mathrm{Chl} a \mathrm{~L}^{-1}$; Izydorczyk et al., 2009).

\section{Microcystin concentrations}

The microcystins LR and RR in samples from Sulejow reservoir and microcystins $\mathrm{RR}$ in lake Białe were identified. The HPLC analysis detected the presence of microcystins in the cells but not in the water of the studied ecosystems.
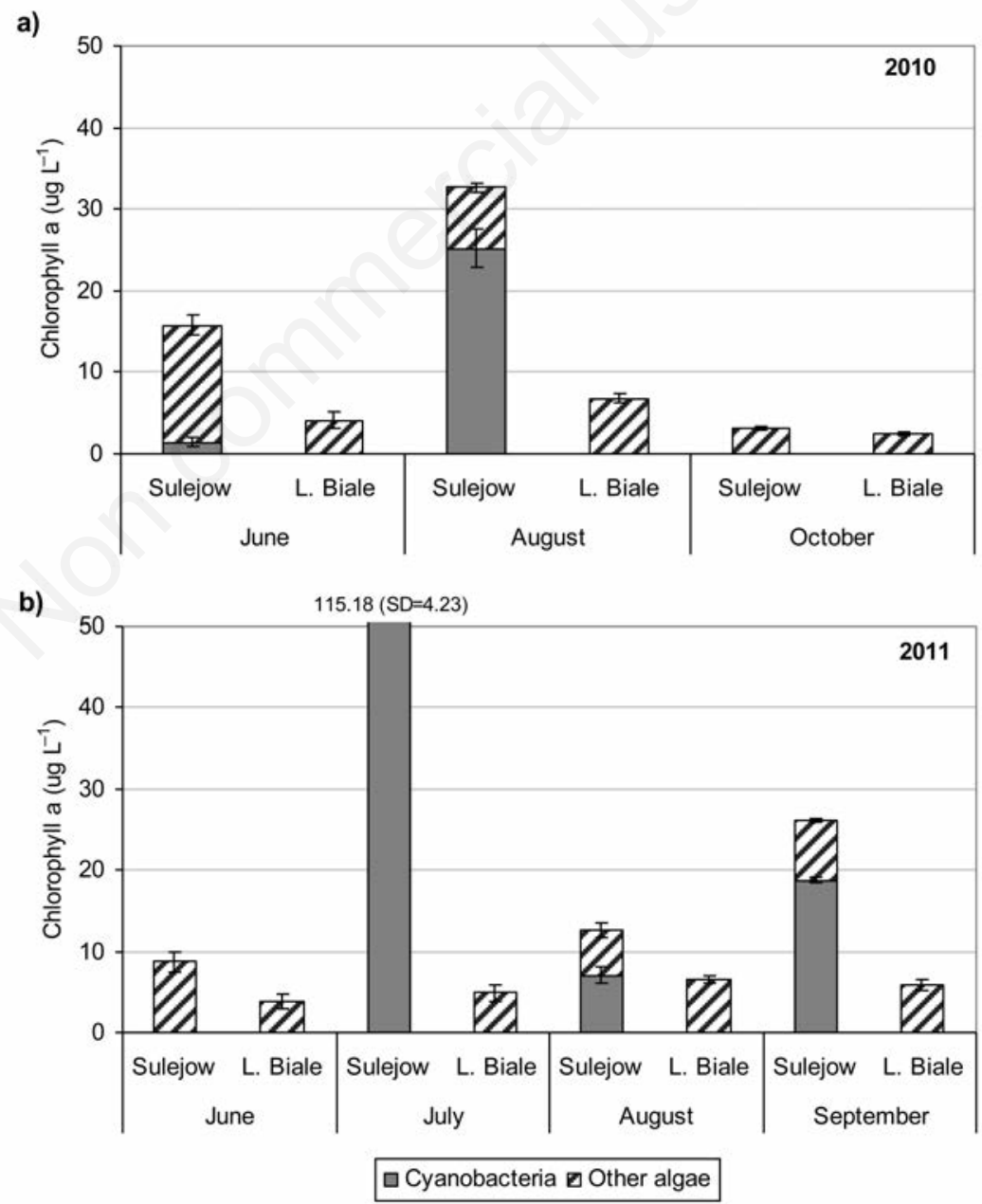

Fig. 2. Chlorophyll $a$ concentrations ( $\mu \mathrm{g} \mathrm{L}^{-1}$ ) in Sulejow reservoir (r.) and lake (L.) Białe during the sampling seasons: a) in 2010 , b) in 2011. The bars represent an average of three fluorometer measurements $( \pm \mathrm{SD})$. 
In June 2010, the concentrations of MC-RR in the cells amounted to $0.931 \mu \mathrm{g} \mathrm{g}^{-1}$, and the concentrations of MC$\mathrm{LR}$ amounted to $1.624 \mu \mathrm{g} \mathrm{g}^{-1}$ in Sulejow reservoir. In August, the concentrations of microcystins increased to 5.549 $\mu \mathrm{g} \mathrm{g}^{-1}$ (MC-RR) and to $0.824 \mu \mathrm{g} \mathrm{g}^{-1}$ (MC-LR). Such high levels of $\mathrm{MC}$ concentrations in the reservoir remained similar until October 2010 (MC-RR: $5.609 \mu \mathrm{g} \mathrm{g}^{-1}$ and MC-LR: $2.816 \mu \mathrm{g} \mathrm{g}^{-1}$ ) (Fig. 3). However, we did not find any microcystins in the extracts from Daphnia spp. tissues collected from Sulejow reservoir in 2010. Conversely, in lake Białe, the presence of MC-RR in cells $\left(0.537 \mu \mathrm{g} \mathrm{g}^{-1}\right.$ in August and $0.384 \mu \mathrm{g} \mathrm{g}^{-1}$ in October) was confirmed in the extracts from Daphnia spp. tissues, where we also detect MC-RR (11.24 $\mu \mathrm{g} \mathrm{g}^{-1}$ wet mass in August and $9.93 \mu \mathrm{g} \mathrm{g}^{-1}$ wet mass in October). The HPLC chromatograms of the microcystin standards and the results from lake Białe from 2010 are presented in Fig. 4. Panel a) shows the MC-RR and MC-LR standards, and panels c) and d) show MC-RR in Daphnia spp. tissues with a retention time of $2.84 \mathrm{~min}$ and a characteristic UV spectrum absorbance (the small graphs). In October's sample we also found a peak in retention time for MC-LR (3.50 min), but with a different UV spectrum absorbance (Fig. 4d), thus we did not classify this compound as MC-LR.
In Sulejow reservoir, the toxicity of cyanobacteria was lower in 2011 than in 2010 (Fig. 3b). In June, the concentrations of MC-RR in the cells amounted to $0.626 \mu \mathrm{g} \mathrm{g}^{-1}$, and the concentrations of MC-LR amounted to $0.343 \mu \mathrm{g}$ $\mathrm{g}^{-1}$. Then, $\mathrm{MC}$ concentrations increased to $1.628 \mu \mathrm{g} \mathrm{g}^{-1}$ (MC-RR) and to $1.131 \mu \mathrm{g} \mathrm{g}^{-1}$ (MC-LR). The maximal value of MC-RR $\left(2.668 \mu \mathrm{g} \mathrm{g}^{-1}\right)$ was observed in September. The highest level of MC-LR concentrations (1.286 $\mu \mathrm{g} \mathrm{g}^{-1}$ ) was reached in August. In the extracts from Daphnia spp. tissues collected from Sulejow reservoir in June 2011, we found $0.56 \mu \mathrm{g} \mathrm{MC-LR} \mathrm{g}{ }^{-1}$ wet mass (Fig. 4b). We did not detect microcystins in the water samples from lake Białe, and we did not find any microcystin contents in the extracts from Daphnia spp. tissues collected from this lake in 2011.

\section{Oxidative stress parameters in Daphnia spp. tissues}

As for 2010, the two-way ANOVA indicated significant seasonal differences in the values of all the studied oxidative stress parameters in Daphnia spp. (Figs. 5a, b, c; Tab. 2). The values of GSH from both water bodies were similar in June and August and significantly higher in October. The lipid peroxidation was the highest in October, significantly lower in June and the lowest in August. The catalase activity

a)

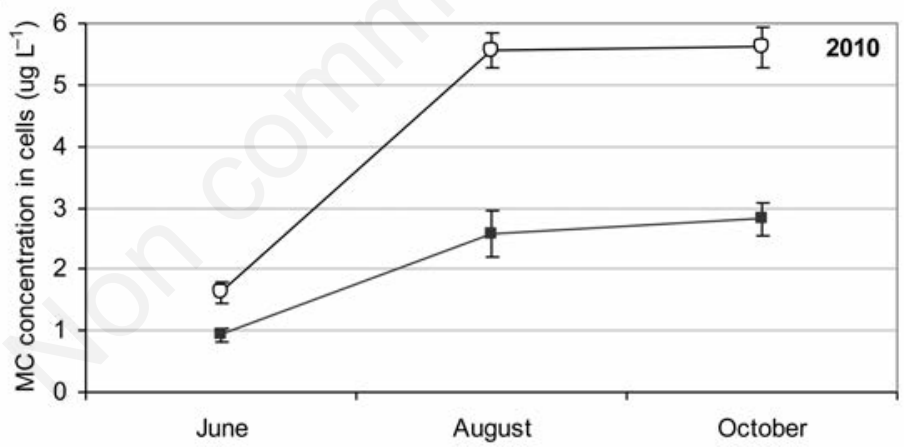

b)

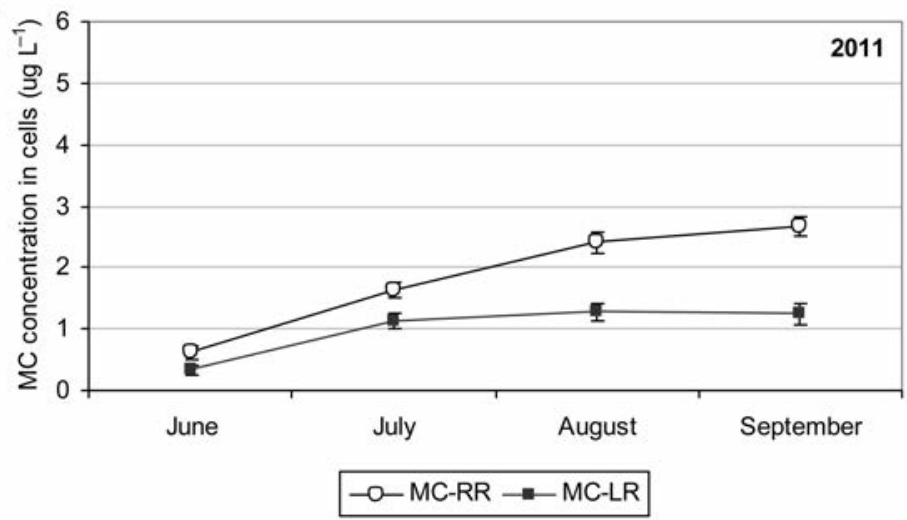

Fig. 3. Microcystin (MC) concentrations in cells $\left(\mu \mathrm{g} \mathrm{L}^{-1}\right)$ in Sulejow reservoir during sampling seasons: a) in 2010 , b) in 2011. 
was similar in August and October, and significantly lower in June. However, the between-lakes differences were significant only for catalase activity. There were also significant season $\times$ lake interactions for all the three analysed parameters, indicating major intra-seasonal differences between these lakes (Tab. 2).

In 2010, the glutathione concentrations in the tissues of daphniids from Sulejow reservoir ranged from 2.54 to $3.30 \mathrm{nmol} \mathrm{GSH} / \mathrm{mg}$ protein, but they did not differ significantly between the seasons (Fig. 5a). The GSH concentrations in the tissues of Daphnia sp. from lake Białe decreased during the seasons (Fig. 5a); the concentrations were the highest in June ( $4.30 \mathrm{nmol} \mathrm{GSH} / \mathrm{mg}$ protein) and the lowest in October (1.52 nmol GSH/mg protein). This autumn value was significantly lower than both spring and summer values. In Sulejow reservoir, the lipid peroxidation of daphniid cells was the highest in June $(0.83 \mathrm{nmol}$ $\mathrm{MDA} / \mathrm{mg}$ protein) and the lowest in August $(0.061 \mathrm{nmol}$ $\mathrm{MDA} / \mathrm{mg}$ protein). In October, the lipid peroxidation reached a medium level $(0.40 \mathrm{nmol} \mathrm{MDA} / \mathrm{mg}$ protein). All of these values for the Sulejow reservoir were significantly different (Fig $5 b$ ). Compared to the changes in the lipid peroxidation of daphniids from the reservoir, the changes in lake Białe showed an opposite tendency: the
LPO levels were low in June $(0.049 \mathrm{nmol} \mathrm{MDA} / \mathrm{mg}$ protein) and August ( $0.086 \mathrm{nmol} \mathrm{MDA} / \mathrm{mg}$ protein), but significantly increased (to $1.14 \mathrm{nmol} \mathrm{MDA} / \mathrm{mg}$ protein) in October (Fig. 5b). In Sulejow reservoir, the catalase activity was the highest in June ( $25.21 \mathrm{U} / \mathrm{mg}$ protein). It decreased to $20.19 \mathrm{U} / \mathrm{mg}$ protein in August and remained on a similar level (20.27 U/mg protein) until October. In contrast, in lake Białe, the catalase activity was the lowest in June (14.13 U/mg protein) and increased during the season to $16.17 \mathrm{U} / \mathrm{mg}$ protein in August and to $17.25 \mathrm{U} / \mathrm{mg}$ protein in October. The catalase activity in 2010 was significantly higher in the daphnid tissues from Sulejow reservoir than from lake Białe (Fig. 5c, Tab. 2).

In 2011, Daphnia spp. individuals were not found in zooplankton samples from lake Białe collected in July. Thus, we analysed three, rather than four, sampling periods for this lake.

For 2011, the one-way ANOVA indicated that there were no significant differences in both the GSH concentrations and LPO levels between the two ecosystems among the seasons studied (Figs. 5d, e; Tab. 2). Seasonal changes were observed in Sulejow reservoir: GSH concentrations were comparable in June and September (1.30 and 1.39 nmol GSH/mg protein, respectively), and significantly
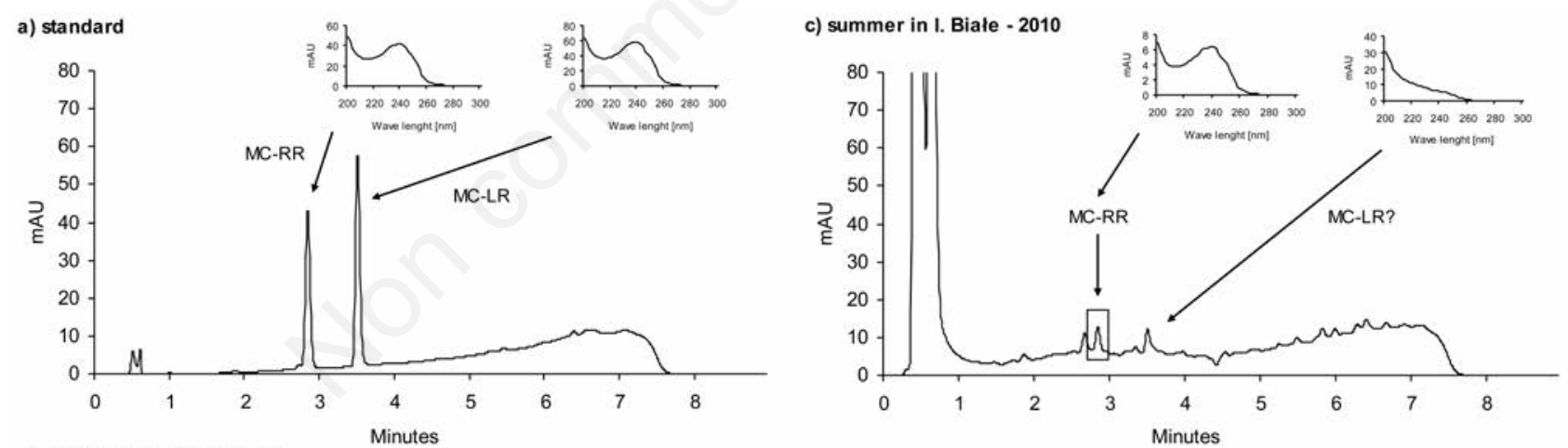

b) spring in Sulejow r. - 2011

d) autumn in I. Białe - 2010
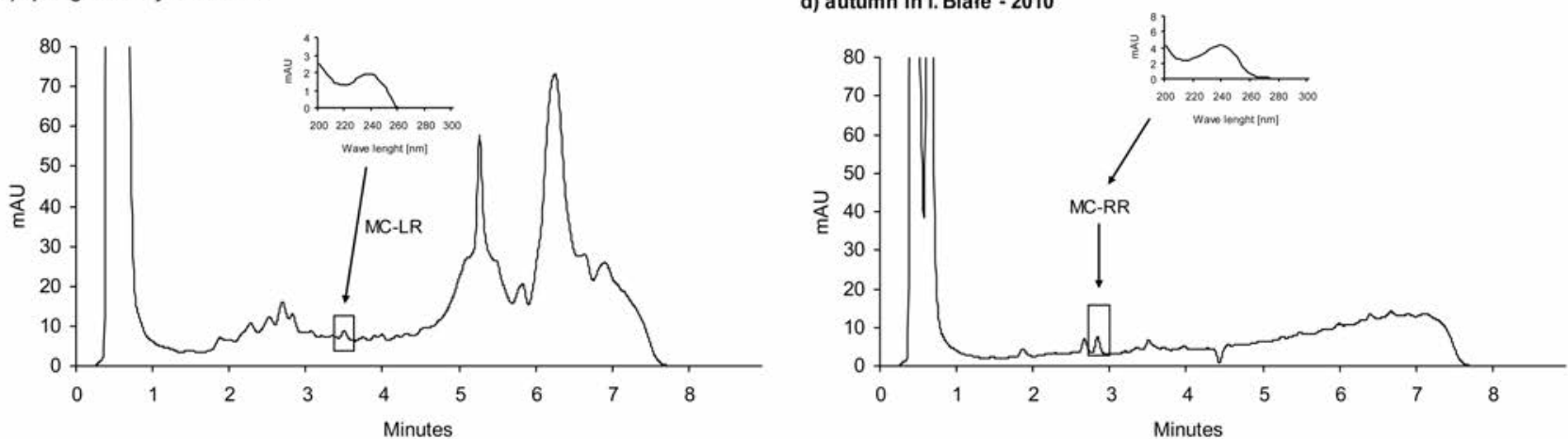

Fig. 4. High performance liquid chromatograms of microcystins (MC) -RR and -LR in the standard (a) and in extracts from Daphnia tissues: b) in spring samples from Sulejow reservoir in 2011, c) in summer and d) autumn samples from lake Białe in 2010. The small graphs show the UV spectrum absorbance characteristic of MC-RR and MC-LR. 
higher than those in July ( $0.96 \mathrm{nmol} \mathrm{GSH} / \mathrm{mg}$ protein) and August ( $0.63 \mathrm{nmol}$ GSH/mg protein). The GSH concentrations from lake Białe did not differ significantly between the seasons (Fig. 5d; Tab 2). The LPO levels from Sulejow reservoir were significantly higher in June $(0.086 \mathrm{nmol}$ $\mathrm{MDA} / \mathrm{mg}$ protein) and August (0.081 nmol MDA/mg protein) than in July $(0.050 \mathrm{nmol} \mathrm{MDA} / \mathrm{mg}$ protein $)$ and September (0.049 $\mathrm{nmol} \mathrm{MDA} / \mathrm{mg}$ protein). In lake Białe, LPO levels were comparable in June $(0.058 \mathrm{nmol} \mathrm{MDA} / \mathrm{mg}$ protein) and August (0.066 nmol MDA/mg protein), and were significantly lower than those in September $(0.117 \mathrm{nmol}$ MDA/mg protein) (Fig. 5e; Tab. 2). According to the oneway ANOVA, the catalase activity differed significantly between Sulejow reservoir and lake Białe among all the studied seasons (Figs. 5c, f; Tab. 2). The activity was always higher in Sulejow reservoir than in lake Białe. In Sulejow reservoir, the CAT activity was higher and less stable in 2011 than in 2010 (Figs. 5c, f). In 2011, the reservoir had the highest catalase activity in July $(40.94 \mathrm{U} / \mathrm{mg}$ protein) and lower activity in June and September (26.09 and a)
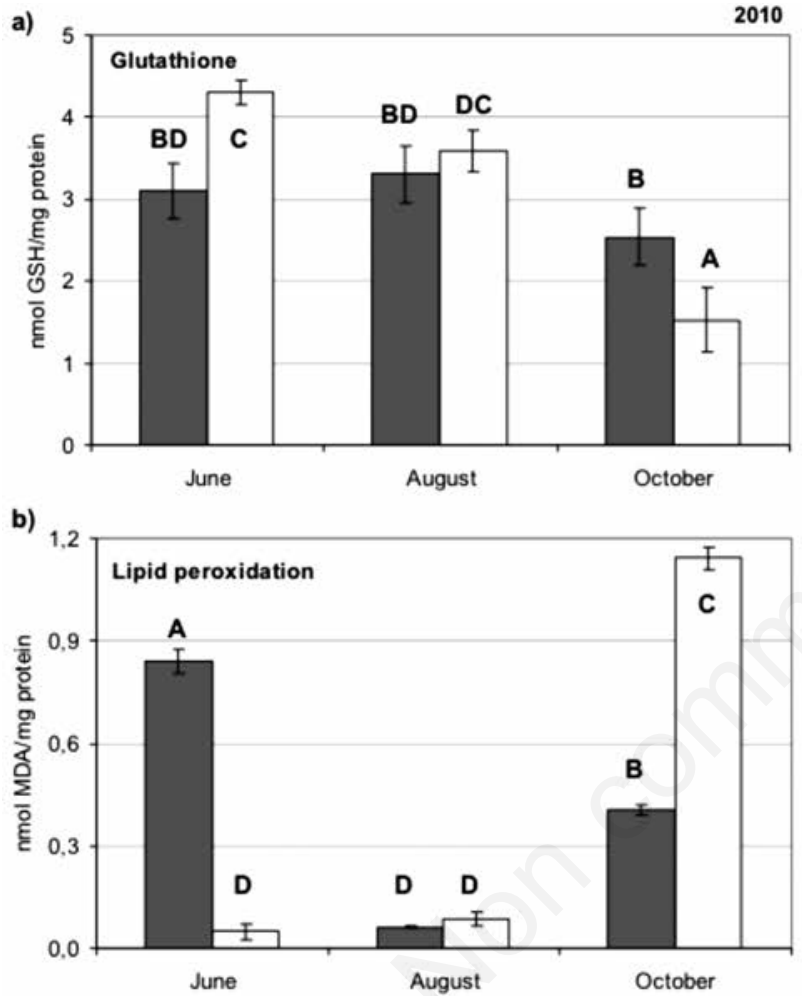

c)

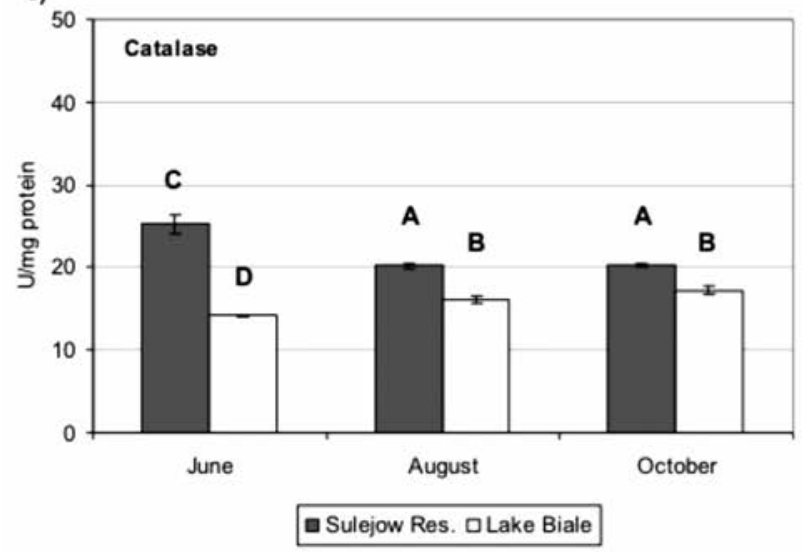

d)
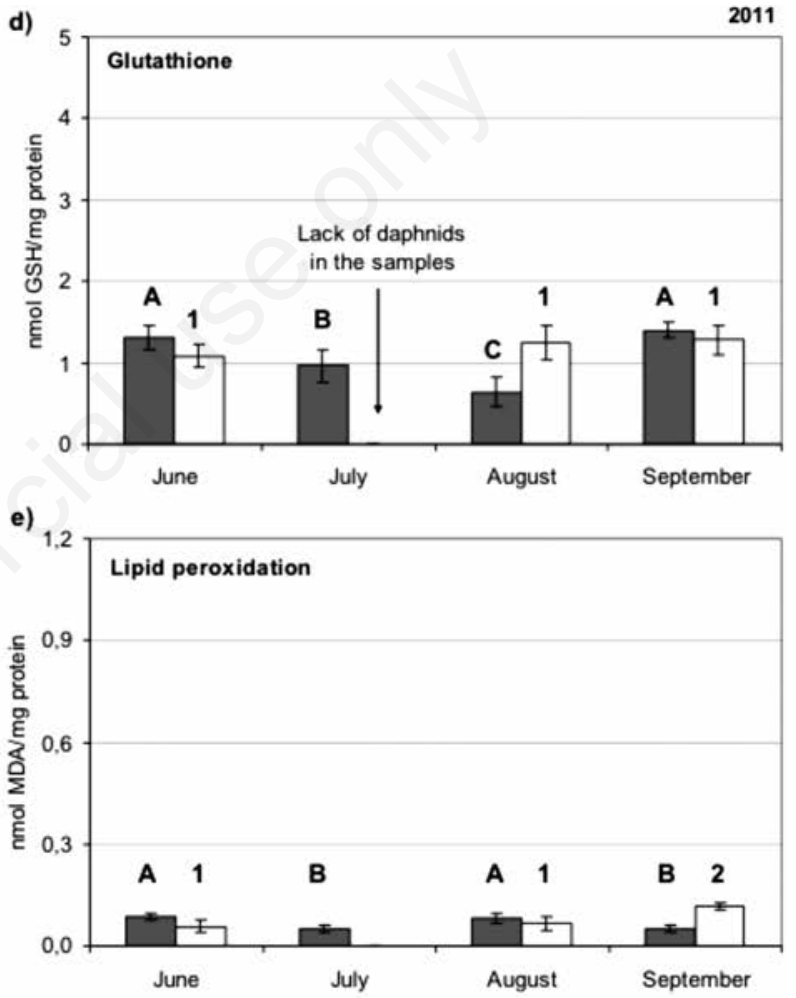

f)

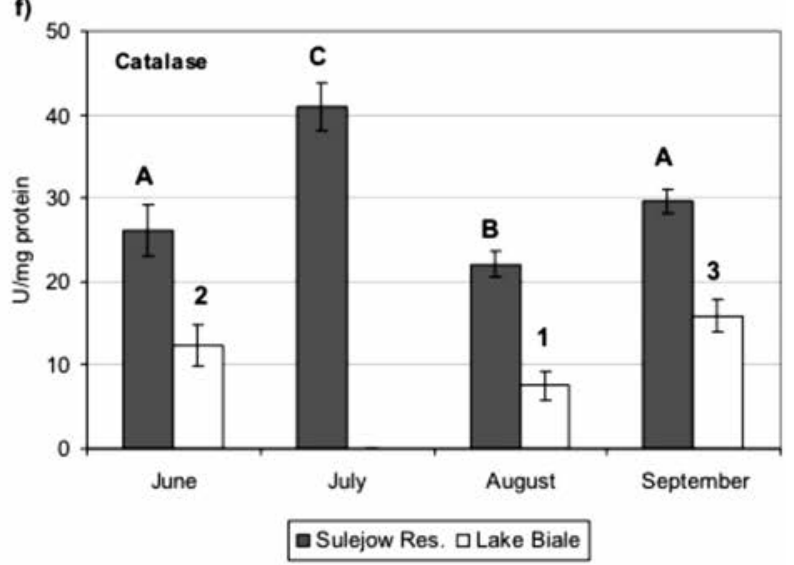

Fig. 5. Comparison of the glutathione concentrations, lipid peroxidation (nmol/mg protein) and catalase activity (U/mg protein) in Daphnia spp. tissues from Sulejow reservoir and lake Białe in 2010 (a, b, c) and 2011 (d, e, f). The bars represent an average of three replicates $( \pm \mathrm{SD})$. The same letters (for Sulejow) and digits (for Białe) above the bars indicate that the values did not differ significantly. 
$29.61 \mathrm{U} / \mathrm{mg}$ protein, respectively). The lowest value of CAT activity (22.10 U/mg protein) was noted in August. In lake Białe, CAT activity was lower in 2011 than in 2010 and amounted to $12.33 \mathrm{U} / \mathrm{mg}$ protein in June, decreasing to $7.51 \mathrm{U} / \mathrm{mg}$ protein in August, and increasing to 15.89 U/mg protein in September (Fig. 5f).

\section{The presence of conjugates in tissues of daphniids}

Microcystins and their conjugates with glutathione in the tissues of Daphnia spp. were identified on the basis of the mass spectrometry (MS) fragmentations of the standard compounds (MC-LR, MC-RR, MC-LR-GSH and MC-RRGSH) (Tab. 3). We detected MC-LR and MC-RR in the tissues of daphniids from all the studied samples from both ecosystems and both years. In both years, the conjugates were also found in our samples (Tab. 4). In 2010, MC-LRGSH and MC-RR-GSH were present in daphniids tissues in August and October (Sulejow reservoir) and only in October in lake Białe. In 2011, these conjugates appeared in daphniids from both ecosystems in August and September. We also identified microcystin conjugates with cysteine in summer and autumn samples from Sulejow reservoir and lake Białe. In both ecosystems in 2011, MC-LR-Cys was present in the tissues of daphniids in August and October, but MC-RR-Cys was found only in October. In 2011, we identified MC-LR-Cys in samples from September in both studied water bodies. MC-RR-Cys appeared only in September's samples from Sulejow reservoir.

\section{DISCUSSION}

Cyanobacterial blooms have been reported in summer in Sulejow reservoir for 30 years (unpublished data). Conversely, the appearance of cyanobacteria was not observed until recently in lake Białe, and, according to the reports of the Polish Inspectorate of Environmental Protection (PIEP), the water quality of lake Biake is characterised as good (second class, consistent with the requirements defined by Polish and EU law; www.wios.warszawa.pl).

Tab. 2. Results of the ANOVA tests for the effects of season and ecosystem type on the oxidative stress parameters measured in Daphnia spp. tissues.

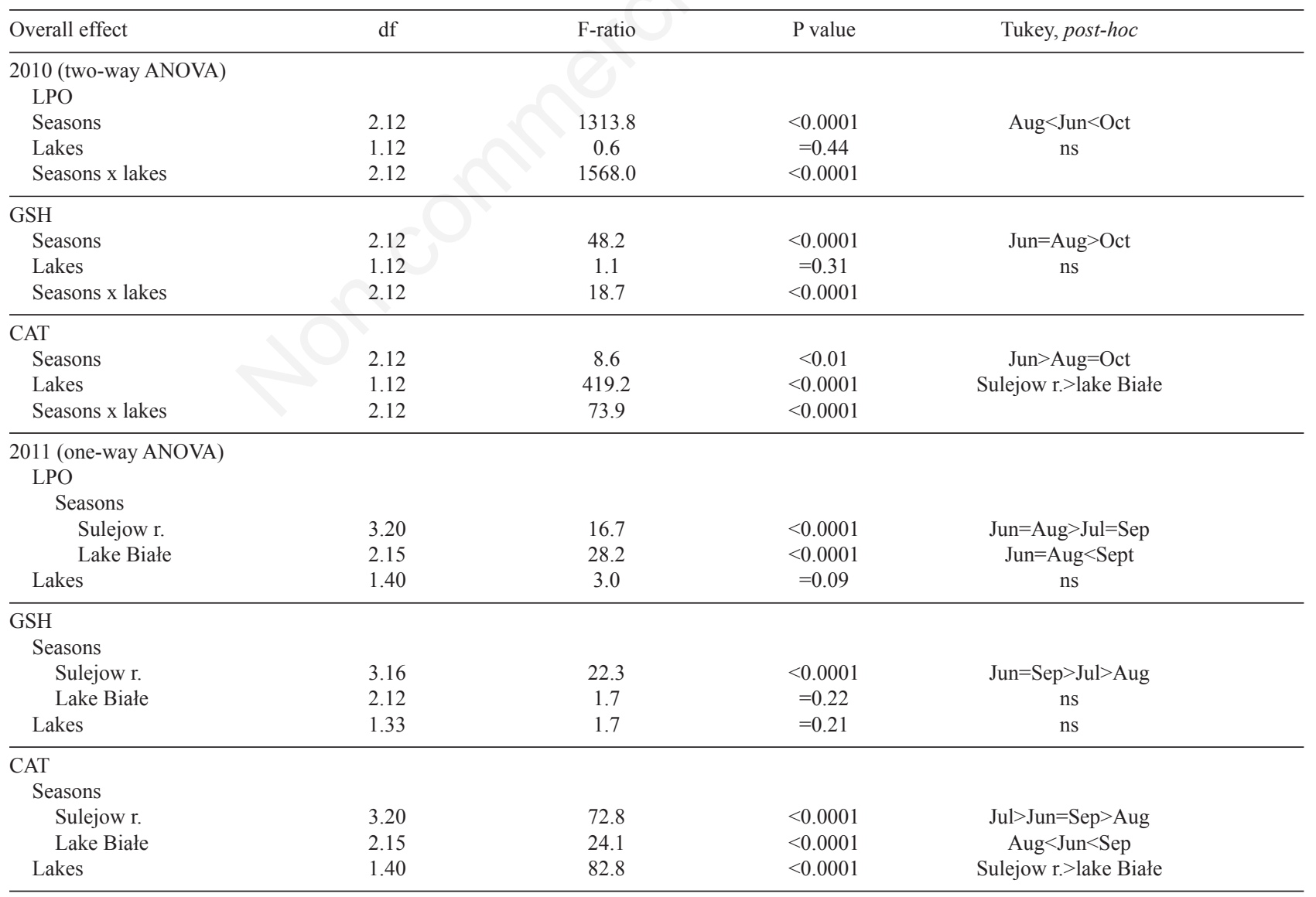

df, degree of freedom; LPO, lipid peroxidation; Aug, August; Jun, June; Oct, October; Sulejow r., Sulejow reservoir; ns, not significant; GSH, glutathione; CAT, catalase. 
However, in 2010, high amounts of organic and mineral substances were flushed from the catchment area into lake Białe due to extreme and long-lasting spring floods. Moreover, this lake has increasingly been used as a recreation area in the last several years. The appearance of cyanobacterial species was observed for the first time in summer samples from lake Białe in 2010 (based on PIEP data), and, in our view, the presence of cyanobacteria could be a consequence of both surface washings from the lake basin (e.g. nutrient inflow during the spring flood) and polluters from the recreation areas. Although the concentration of M. aeruginosa in lake Białe was below the detection limit of the AOA fluorometer (Figs. 2a, b) (Izydorczyk et al., 2009), it could have influenced the pelagic filter feeders, as discussed below.

\section{Daphniid sensitivity to microcystin toxicity}

We assumed that the different trophic states and cyanobacterial concentrations in Sulejow reservoir and lake Białe would allow the observation of different reaction norms of daphniids under the influence of cyanobacteria. Our hypothesis was based on the literature indicating that the susceptibility of zooplankton to cyanotoxins may be diverse. Although many studies have reported a reduction of Daphnia survival when exposed to cyanobacterial toxins (e.g. Lampert 1981; De Bernardi and Giussani, 1990, Rohrlack et al., 1999), there are also some reports demonstrating that Daphnia populations repeatedly exposed to toxic Microcystis in their natural habitat were more resistant to the toxin than populations lacking a prior exposure (e.g. Nandini, 2000; Gustafsson and Hansson, 2004). Thus, as Hairston et al. (1999, 2001) suggested, the evolution of resistance to cyanobacterial toxins within Daphnia species or clones reflects a recent exposure to these toxins. Additionally, the trophy of an ecosystem seems to be an important factor determining the sensitivity of daphniids to cyanotoxins: a positive spatial association between the tolerance of cyanobacteria by D. pulicaria and the prevalence of cyanobacteria in highTP lakes was observed by Sarnelle and Wilson (2005).

Indeed, our results demonstrate that the Daphnia spp. exposed for the first time to cyanobacterial toxins (2010, in mesotrophic lake Białe) are more susceptible to their toxic effects than the daphniids that constantly coexist with cyanobacteria (in the eutrophic Sulejow reservoir). First, this conclusion was supported by the much higher accumulation of MCs in the tissues of Daphnia spp. in lake Białe, despite the low toxin concentrations in this ecosystem compared to the Sulejow reservoir (see Fig. 3). We focused on the HPLC results, as this technique has a greater limit of toxin detection $\left(>10 \mathrm{ng} \mathrm{L}^{-1}\right)$ than HPLCESI-MS/MS (even detecting single molecules). Thus, we were able to consider those MC concentrations that might be significant for both the daphniids organisms themselves and also for the food web function due to the possibility of elevated cyanobacterial toxin concentrations being transported to higher consumers (Martins and Vasconcelos, 2009, but see also Ibelings et al., 2005).

Some studies showed that MC-RR, which is less toxic than MC-LR, is principally taken up into the tissues of aquatic biota (Ibelings and Chorus, 2007). Meriluoto et al. (1990) showed that minor structural differences between MC-LR and -RR may have major effects on the uptake, organ distribution and excretion of these toxins. The observations of Xie et al. (2004) suggested that MC-LR may be actively degraded during digestion, whereas MC-RR is transported across the intestines and embedded into body tissues. We observed both MC-RR and MC-LR in the daph-

Tab. 3. Mass spectrometry fragmentation of the investigated microcystins and their glutathione and cysteine conjugates by HPLC-ESIMS/MS.

\begin{tabular}{lll}
\hline Compounds & MS precursor fragment ions & $\mathrm{m} \mathrm{z}^{-1}$ \\
\hline MC-LR & {$[\mathrm{M}+\mathrm{H}]^{+} ;[\mathrm{M}-\mathrm{Glu}+\mathrm{H}]^{+} ;\left[\mathrm{M}-\mathrm{H}_{2} \mathrm{O}+\mathrm{H}\right]^{+}$} & $995.5 ; 866.4 ; 977.5 ;$ \\
\hline MC-LR-GSH & {$[\mathrm{M}+\mathrm{H}]^{+} ;[\mathrm{M}+2 \mathrm{H}]^{2+} ;[\mathrm{M}-\mathrm{Glu}+\mathrm{H}]^{+} ;\left[\mathrm{M}-\mathrm{H}_{2} \mathrm{O}+\mathrm{H}\right]^{+} ;$} & $1302.5 ; 652.0 ; 1173.5 ; 1284.5 ;$ \\
& {$\left[\mathrm{M}-\mathrm{H}_{2} \mathrm{O}-\mathrm{Gly}+\mathrm{H}\right]^{+} ;[\mathrm{M}-\mathrm{Glu}+\mathrm{Gly}+\mathrm{H}]^{+} ;$} & $1209.5 ; 1116.5 ;$ \\
\hline MC-LR-Cys & {$\left[\mathrm{M}-\mathrm{Glu}+\mathrm{H}_{2} \mathrm{O}+\mathrm{H}\right]^{+} ;[\mathrm{M}-\mathrm{GSH}+\mathrm{H}]^{+}$} & $1155.5 ; 995.5$ \\
\hline MC-RR & {$[\mathrm{M}+\mathrm{H}]^{+} ;\left[\mathrm{M}-\mathrm{H}_{2} \mathrm{O}+\mathrm{H}\right]^{+} ;[\mathrm{M}-\mathrm{Glu}+\mathrm{H}]^{+} ;[\mathrm{M}-\mathrm{Cys}+\mathrm{H}]^{+}$} & $1116.5 ; 1098.5 ; 987.5 ; 955.5$ \\
\hline MC-RR-GSH & {$[\mathrm{M}+\mathrm{H}]^{+} ;[\mathrm{M}-\mathrm{Glu}+\mathrm{H}]^{+} ;\left[\mathrm{M}-\mathrm{H}_{2} \mathrm{O}+\mathrm{H}\right]^{+} ;[\mathrm{M}+2 \mathrm{H}]^{2+}$} & $1038.6 ; 909,6 ; 1020.6 ; 519.8 ;$ \\
\hline MC-RR-Cys & {$[\mathrm{M}+\mathrm{H}]^{+} ;[\mathrm{M}+2 \mathrm{H}]^{2+} ;[\mathrm{M}-\mathrm{Glu}+\mathrm{H}]^{+} ;\left[\mathrm{M}-\mathrm{H}_{2} \mathrm{O}+\mathrm{H}\right]^{+} ;$} & $1345.6 ; 673.8 ; 1216.6 ; 1327.6 ;$ \\
& {$\left[\mathrm{M}-\mathrm{H}_{2} \mathrm{O}-\mathrm{Gly}+\mathrm{H}\right]^{+} ;[\mathrm{M}-\mathrm{Glu}+\mathrm{Gly}+\mathrm{H}]^{+} ;$} & $1252.3 ; 1159.6 ;$ \\
\hline $\left.\mathrm{M}-\mathrm{Glu}+\mathrm{H}_{2} \mathrm{O}+\mathrm{H}\right]^{+} ;[\mathrm{M}-\mathrm{GSH}+\mathrm{H}]^{+}$ & $1198.6 ; 1038.6$ \\
\hline
\end{tabular}

$M S$, mass spectrometry; MC-LR, microcystin-LR; MC-LR-GSH, microcystin LR-GSH; MC-LR-Cys, microcystin-LR-Cys; MC-RR, microcystin-RR; MCRR-GSH, microcystin-RR-GSH; MC-RR-Cys, microcystin-RR-Cys. 
niid tissues in our study, and the concentration of microcystins varied throughout the years in both lake Białe and Sulejow reservoir. In lake Białe, the daphniids accumulated MCs with higher toxicity in 2010, whereas, in Sulejow reservoir, generally characterised by a high concentration of cyanotoxins, the accumulation of MCs in the Daphnia spp. was observed during the period of the lowest toxicity (spring of 2011). Thus, we hypothesised that the detoxification processes that protect Daphnia spp. against MC accumulation in their tissues may only be activated above some critical concentration of microcystins in the animals' cells ( $>0.343 \mu \mathrm{g} \mathrm{MC-LR} \mathrm{L}{ }^{-1}$, according to our results). However, this hypothesis requires verification.

\section{Cyanotoxins as oxidative stressors for daphniids}

Additional evidence that the daphniids from lake Białe were more susceptible to cyanotoxins than those from Sulejow reservoir was provided by comparing the seasonal changes in levels of LPO, as an oxidative stress parameter, and the GSH concentrations, as an intracellular antioxidant, reflecting the toxic impact of the cyanobacteria. Microcystins induce oxidative stress in animal cells (Campos and Vasconcelos, 2010), which is related to the production of reactive oxygen species (ROS) and leads to an increase in lipid peroxidation (Amado and Monserrat, 2010). Lipid peroxidation contributes to an impaired cellular function and alterations in the physical and chemical properties of cell membranes, which, in turn, disrupt vital functions (Rikans and Hornbrook, 1997). In lake Białe, in 2010 - a year when we observed MC-RR in Daphnia's tissues - the level of LPO was low in spring and summer but significantly higher in autumn, indicating that the oxidative stress mainly intensified during this period. Conversely, the LPO level in Sulejow reservoir was significantly lower in August (despite the presence of blooms) and October than in June. These results indicate that the appearance of cyanobacteria did not induce oxidative stress in the daphniids of Sulejow reservoir (Fig. 5b). This may also point out the presence of a relationship between LPO level and content of polyunsaturated fatty acids (PUFAs) in the food sources. PUFAs are particularly prone to peroxidation (Pan et al., 2004), thus the low LPO level during blooms of PUFA-poor cyanobacteria might result from a lower PUFA content in Daphnia spp., whereas the increased LPO level in daphniids body during spring might reflect a higher PUFA content in eukaryotic food sources (e.g. Eritsland, 2000; MüllerNavarra et al., 2004).

In lake Białe, a significant decrease in GSH occurred together with an increase in the LPO level in October 2010 (Fig. 5a). Because glutathione, considered to be one of the most important low molecular weight cellular antioxidants, is involved in the protection of cell membranes from lipid peroxidation (Meister, 1989), it is probable that the depletion of GSH results in cell membrane damage, with a consequent efflux of GSH (Ding et al., 2000;

Tab. 4. Terms in which microcystins and their glutathione and cysteine conjugates were identified.

\begin{tabular}{|c|c|c|c|c|c|c|}
\hline Material & MC-LR & MC-RR & MC-LR-GSH & MC-RR-GSH & MC-LR-Cys & MC-RR-Cys \\
\hline MC-LR-GS in vitro & + & - & + & - & - & - \\
\hline $\mathrm{MC}-\mathrm{RR}-\mathrm{GS}$ in vitro & - & + & - & + & - & - \\
\hline \multicolumn{7}{|l|}{2010 - Sulejow r. } \\
\hline June & + & + & - & - & - & - \\
\hline August & + & + & + & + & + & - \\
\hline October & + & + & + & + & + & + \\
\hline \multicolumn{7}{|l|}{$2010-1$. Białe } \\
\hline June & + & + & - & - & - & - \\
\hline August & + & + & - & - & + & - \\
\hline October & + & + & + & + & + & + \\
\hline \multicolumn{7}{|l|}{2011 - Sulejow r. } \\
\hline June & + & + & - & - & - & - \\
\hline July & + & + & - & - & - & - \\
\hline August & + & + & + & + & - & - \\
\hline September & + & + & + & + & + & + \\
\hline \multicolumn{7}{|l|}{$2011-1$. Białe } \\
\hline June & + & + & - & - & - & - \\
\hline July - lack of samples & - & - & - & - & - & - \\
\hline August & + & + & + & + & - & - \\
\hline September & + & + & + & + & + & - \\
\hline
\end{tabular}


Amado and Monserrat, 2010). The decrease in GSH concentration was related to the elevated accumulation of cyanobacterial toxins in the bodies of the daphniids of lake Białe, an effect similar to that observed by Chen et al. (2005). In 2011, the toxicity of the blooms in Sulejow reservoir was considerably lower than in 2010, though the biomass of cyanobacteria showed the opposite trend (Figs. 2, 3). Similarly, because the 2011 level of cyanotoxins in lake Białe was not detectable by HPLC, we infer that it was lower than the 2010 level. The lower probability of oxidative stress enhancement by MCs may have resulted in lower concentrations of GSH and also lower levels of LPO in 2011 than in 2010 in both the ecosystems under study. In Sulejow reservoir, GSH concentrations decreased when the cyanobacteria were most abundant and may be the result of cell membrane damage and also the use of GSH in antioxidant processes during massive blooms. The stable dynamics of GSH and LPO in lake Białe indicated that cyanobacteria-induced oxidative stress in the daphniids of this ecosystem did not occur in 2011. In both years, the catalase activity was always higher in Sulejow reservoir than in lake Białe (Figs. 5c, f). As CAT reduces relatively high concentrations of $\mathrm{ROS} \mathrm{H}_{2} \mathrm{O}_{2}$ (Fridovich, 1998), the elevated activity of this enzyme reflects more efficient oxidative protection (Ortiz-Rodríguez and Wiegand, 2010). In particular, the CAT activity in 2011 was directly related to the toxin concentrations and acted to buffer the oxidative stress in the daphniids of Sulejow reservoir.

\section{Ability of microcystin detoxification by daphniids}

The results discussed above support our hypothesis that the generations of the daphniids of Sulejow reservoir had more effective antioxidant systems to protect them against the accumulation of cyanobacterial toxins than the daphniids of lake Białe. However, the presence of conjugate forms of microcystins in the tissues of the studied animals indicated the ability for MC detoxification by the daphniids from both of the ecosystems. In this biodegradation process, GSH plays a particularly important role because the chemical conjugation of MCs with GSH is recognised as the first step of detoxification in aquatic organisms exposed to cyanobacterial toxins (Pflugmacher et al., 1998). Research by Kondo et al. (1996), Pflugmacher et al. $(1998,2001)$ and Metcalf et al. (2000) determined that MC-GSH conjugates are then degraded into cysteine conjugates, which are further transformed into $\mathrm{N}$-acetyl cysteine conjugates and resulting in novel nephrotoxicity (Dekant, 2001). The production of conjugates reduces the toxicity of MCs and facilitates their excretion by organisms (Pflugmacher et al., 1998). Interestingly, a similar pattern of conjugate production by the daphniids in both ecosystems was observed in our study: conjugates were never present in the tissues in June and appeared only in the summer samples (Tab. 4). These results indicated that the conjugates were not formed during spring, which may support our presumption that the detoxification process begins above threshold levels of microcystins accumulated in the tissues of daphniids. In August, both MC-LR-GSH and MC-RR-GSH were observed in the tissues of the Daphnia spp. (except for lake Białe in 2010). Although cysteine conjugates with MCLR and MC-RR were more frequently detected in the samples from September and October in both ecosystems (Tab. 4), we did not determine this shift to be related to the GSH content and/or MC toxicity level.

The daphniid ability for MC biodegradation through conjugate production in both the studied water bodies implies that daphniids have a high capacity for adaptation to environmental changes, even within a single growing season. Such a high phenotypic plasticity is determined by a distinguishing structural feature in the daphniid genome: an elevated rate of gene duplication resulting in tandem gene clusters (Boucher et al., 2010; Colbourne et al., 2011). The gene-rich genome of Daphnia allows these species to activate rapidly those genes that are indispensable under the current environmental conditions (Stillman et al., 2008). Thus, the enzymatic pathway for the degradation of MCs by forming conjugates with GSH is fixed genetically. For daphniids, this property seems to be species-independent, as the different Daphnia species reacted in the same way in our study. However, the different sensitivity levels of Daphnia species to the harmful effects of cyanobacteria in the natural environment is the result of a selective pressure exerted by toxic cyanobacterial strains: the strains favour the most resistant species or clones due to their individual adaptations (Hietala et al., 1997; Barros et al., 2001). Therefore, our results suggest that the highly effective antioxidant systems in the daphniids of Sulejow reservoir - which have long coexisted with cyanobacteria - resulted from the selection of the most resistant genotypes.

\section{ACKNOWLEDGMENTS}

This study was supported by the Polish Ministry of Science and Higher Education (Grant No. 3988/B/P01/ 2010/39).

\section{REFERENCES}

Aebi H, 1984. Catalase in vitro. Method Enzymol. 105:121-126.

Amado LL, Monserrat JM, 2010. Oxidative stress generation by microcystins in aquatic animals: why and how. Environ. Int. 36:226-235.

Barros P, Fidalgo ML, Soares AMVM. 2001. Resistance of cladoceran species to toxic Microcystis. Limnetica 20:173177.

Benzie JAH, 2005. The genus Daphnia (including Daphniopsis) (Anomopoda: Daphniidae). Guides to the identification of 
the macroinvertebrates of the continental waters of the world. 21. Kenobi Productions. Ghent and Backhuys Publ., Leiden.

Bouaïcha N, Maatouk I, 2004. Microcystin-LR and nodularin induce intracellular glutathione alteration, reactive oxygen species production and lipid peroxiation in primary cultured rat hepatocytes. Toxicol. Lett. 148:53-63.

Boucher P, Ditlecadet D, Dubé C, Dufresne F, 2010. Unusual duplication of the insulin-like receptor in the crustacean Daphnia pulex. BMC Evol. Biol. 10:305.

Burns CW, Forsyth DJ, Haney JF, James MR, Lampert W, Primore RD, 1989. Coexistence and exclusion of zooplankton by Anabena minutissima var. attenuate in Lake Rotongaio, New Zealand. Arch. Hydrobiol. 32:63-82.

Cagnard O, Boudin I, Lemoigne I, Cartnick K, 2006. Assessment of emerging optic sensors (fluoroprobes) for algae online monitoring, p. 1-10. In: Proc. Conf. Water Quality Technology Conference (WQTC). American Water Works Association, Denver, CO, USA.

Campos A, Vasconcelos V, 2010. Molecular mechanisms of microcystin toxicity in animal cells. Int. J. Mol. Sci. 11:268-287.

Chen W, Song L, Ou D, Gan N, 2005. Chronic toxicity and responses of several important enzymes in Daphnia magna on exposure to sublethal microcystin-LR. Environ. Toxicol. 20:323-330.

Choiński A, 2006. [Katalog jezior Polski] (Catalogue of Poland's lakes). [in Polish]. Wydawnictwo Naukowe UAM ed., Poznan.

Colbourne JK, Pfrender ME, Gilbert D, Thomas WK, Tucker A, Oakley TH, Tokishita S, Aerts A, Arnold GJ, Basu MK, Bauer DJ, Cáceres CE, Carmel L, Casola C, Choi J-H, Detter JC, Dong Q, Dusheyko S, Eads BD, Fröhlich T, GeilerSamerotte KA, Gerlach D, Harcher P, Jogdeo S, Krijgsveld J, Kriventseva EV, Kültz D, Laforsch C, Lindquist E, Lopez J, Manak JR, Muller J, Pangilinan J, Patwardhan RP, Pitluck S, Pritham EJ, Rechtsteiner A, Rho M, Rogozin IB, Sakarya O, Salamov A, Schaack S, Shapiro H, Shiga Y, Skalitzky C, Smith Z, Souvorov A, Sung W, Tang Z, Tsuchiya D, Tu H, Vos H, Wang M, Wolf YI, Yamagata H, Yamada T, Ye Y, Shaw JR, Andrews J, Crease TJ, Tang H, Lucas SM, Robertson HM, Bork P, Koonin EV, Zdobonv EM, Grigoriev IV, Lynch M, Boore JL, 2011. The ecoresponsive genome of Daphnia pulex. Science 331:555-561.

De Bernardi R, Giussani G, 1990. Are blue-green algae a suitable food for zooplankton? An overview. Hydrobiologia 200/201:29-41.

Dekant W, 2001. Chemical-induced nephrotoxicity mediated by glutathione S-conjugate formation. Toxicol. Lett. 124:2136.

DeMott WR, Zhang QX, Carmichael WW, 1991. Effects of toxic cyanobacteria and purified toxins on the survival and feeding of a copepod and three species of Daphnia. Limnol. Oceanogr. 36:1346-1357.

DeMott WR, 1999. Foraging strategies and growth inhibition in five daphniids feeding on mixtures of a toxic cyanobacterium and a green alga. Freshwater Biol. 42:263-274.

Ding W-X, Shen HM, Ong C-N, 2000. Microcystis cyanobacteria extract induces cytoskeletal disruption and intracellular glutathione alteration in hepatocytes. Environ. Health Persp. 108:605-609.
Eritsland J, 2000. Safety considerations of polyunsaturated fatty acids. Am. J. Clin. Nutr. 71(Suppl. 1):S197-S201.

Fridovich I, 1998. Oxygen toxicity: a radical explanation. J. Exp. Biol. 201:1203-1209.

Fulton RS, Paerl HW, 1987. Toxic and inhibitory effects of the blue green alga Microcystis aeruginosa on herbivorous zooplankton. J. Plankton Res. 9:837-855.

Gérard C, Poullain V, Lance E, Acou A, Brient L, Carpentier A, 2009. Influence of toxic cyanobacteria on community structure and microcystin accumulation of freshwater mollusks. Environ. Pollut. 157:609-617.

Gliwicz ZM, Lampert W, 1990. Food thresholds in Daphnia species in the absence and presence of blue-green filaments. Ecology 71:691-702.

Gliwicz ZM, Siedlar E, 1980. Food size limitation and alga interfering with food collection in Daphnia. Arch. Hydrobiol. $88: 155-177$.

Goldberg J, Huang H, Kwon Y, Greengard P, Nairn AC, Kuriyan J, 1995. Three dimensional structure of the catalytic subunit of protein serine/threonine phosphatase-1. Nature 376:745753.

Golterman HL, Clymo RS, Ohstand MAM, 1978. Methods for physical and chemical analysis of freshwater. Blackwell Scientific Publ., London.

Guo N, Xie P, 2006. Development of tolerance against toxic Microcystis aeruginosa in three cladocerans and the ecological implications. Environ. Pollut. 143:513-518.

Gustafsson S, Hansson L-A, 2004. Development of tolerance against toxic cyanobacteria in Daphnia. Aquat. Ecol. 38:3744.

Hach, 1997. Water analysis handbook. Hach Company ed., Loveland.

Hairston NG Jr., Holtmeier CL, Lampert W, Weider LJ, Post DM, Fischer JM, Cáceres CE, Fox JA, Gaedke U, 2001. Natural selection for grazer resistance to toxic cyanobacteria: evolution of phenotypic plasticity? Evolution 55:22032214.

Hairston NG Jr., Lampert W, Cáceres CE, Holtmeier CL, Weider LJ, Gaedke U, Fischer JM, Fox JA, Post DM, 1999. Rapid evolution revealed by dormant eggs. Nature 401:446.

Hietala J, Laurén-Määttä C, Walls M, 1997. Life history responses of Daphnia clones to toxic Microcystis at different food levels. J. Plankton Res. 19:917-926.

Ibelings BW, Bruning K, de Jonge J, Wolfstein K, Dionisio Pires LM, Postma J, Burger T, 2005. Distribution of microcystins in a lake foodweb: no evidence for biomagnification. Microb. Ecol. 49:487-500.

Ibelings BW, Chorus I, 2007. Accumulation of cyanobacterial toxins in freshwater "seafood" and its consequences for public health: a review. Environ. Pollut. 150:177-192.

Izydorczyk K, Carpentier C, Mrówczyński J, Wagenvoort A, Jurczak T, Tarczyńska M, 2009. Establishment of an Alert Level Framework for cyanobacteria in drinking water resources by using the Algae Online Analyser for monitoring cyjanobacterial chlorophyll $a$. Water Res. 43:989-996.

Jurczak T, Tarczyńska M, Izydorczyk K, Mankiewicz J, Zalewski M, Meriluoto J, 2005. Elimination of microcystins by water treatment process - examples from Sulejow Reservoir, Poland. Water Res. 39:2394-2406.

Jurczak T, Tarczyńska M, Karlsson K, Meriluoto J, 2004. Char- 
acterization and diversity of cyanobacterial hepatotoxins (microcystins) in blooms from Polish freshwaters identified by Liquid Chromatography-Electrospray Ionisation Mass Spectrometry. Chromatographia 59:571-578.

Komarek J, 1991. A review of water-bloom forming Microcystis species, with regard to populations from Japan. Arch. Hydrobiol./Algol. Stud. 64:115-127.

Komarek J, Anagnostidis K, 1999. [Cyanoprokaryota. Teil: Chroococcales]. [in German]. In: H. Ettl, J. Gartner, H. Heyning, D. Mollenhauer (eds.), Süsswasserflora von Mitteleuropa 19/1. Gustav Fischer Verlag, Jena.

Kondo F, Matsumoto H, Yamada S, Ishikawa N, Ito E, Nagata S, Ueno Y, Suzuki M, Harada K-I, 1996. Detection and identification of metabolitem of microcystin formed in vivo in mouse and rat livers. Chem. Res. Toxicol. 9:1355-1359.

Krammer K, Lange-Bertalot H, 1986. Bacillariophyceae 1. Naviculaceae. In: H. Ettl, J. Gartner, H. Heyning, D. Mollenhauer (eds.), Süsswasserflora von Mitteleuropa 12/1. Gustav Fischer Verlag, Jena.

Krammer K, Lange-Bertalot H, 1988. [Bacillariophyceae 2. Bacillariaceae, Epithemiaceae, Surirellaceae]. [in German]. In: H. Ettl, J. Gartner, H. Heyning, D. Mollenhauer (eds.), Süsswasserflora von Mitteleuropa 2/2. Gustav Fischer Verlag, Jena.

Krammer K, Lange-Bertalot H, 1991a. [Bacillariophyceae 3. Centrales, fragilariaceae, Eunotiaceae]. [in German]. In: H. Ettl, J. Gartner, H. Heyning, D. Mollenhauer (eds.), Süsswasserflora von Mitteleuropa 2/3. Gustav Fischer Verlag, Jena.

Krammer K, Lange-Bertalot H, 1991b. [Bacillariophyceae 4. Achnanthaceae. Kritsche Ergänzngen zu Navicula (Lineolatae) und Gomphonema]. [in German]. In: H. Ettl, J. Gartner, H. Heyning, D. Mollenhauer (eds.), Süsswasserflora von Mitteleuropa 2/4. Gustav Fischer Verlag, Jena.

Lampert W, 1981. Inhibitory and toxic effects of blue green algae on Daphnia. Int. Rev. Ges. Hydrobio. 66:285-298.

Lampert W, 1982. Further studies on the inhibitory effect of the toxic blue-green Microcystis aeruginosa on the filtering rate of zooplankton. Arch. Hydrobiol. 95:207-220.

Lowry OH, Rosenbrough NJ, Farr AL, Randal RJ, 1951. Protein measurement with Folin phenol reagent. J. Biol. Chem. 193:265-275.

Lürling M, 2003. Effects of microcystin-free and microcystincontaining strains of the cyanobacterium Microcystis aeruginosa on growth of the grazer Daphnia magna. Environ. Toxicol. 18:202-210.

Martin-Creuzburg D, Von Elert E, Hoffmann KH, 2008. Nutritional constraints at the cyanobacteria-Daphnia magna interface: the role of sterols. Limnol. Oceanogr. 53:456468.

Martins JC, Vasconcelos VM, 2009. Microcystin dynamics in aquatic organisms. J. Toxicol. Env. Heal. B 12:65-82.

Meister A, 1989. On the biochemistry of glutathione, p. 3-22. In: N. Higashi, T. Sakamoto, S. Meister (eds.), Glutathione centennial. Molecular perspectives and clinical implications. Academic Press, San Diego.

Meriluoto JAO, Eriksson JE, Harada K, Dahlem AM, Sivonen K, Carmichael W, 1990. Internal surface reversed-phase high performance liquid-chromatographic separation of the cyanobacterial peptide toxins Microcystin-LA, -LR, -YA, RR and Nodularin. J. Chromatogr. 509:390-395.
Metcalf JS, Beattie KA, Pflugmacher S, Codd GA, 2000. Immuno-crossreactivity and toxicity assessment of conjugation products of the cyanobacterial toxin, microcystin-LR. FEMS Microbiol. Lett. 189:155-158.

Müller-Navarra DC, Brett MT, Park S, Chandra S, Ballantyne AP, Zorita E, Goldman CR, 2004. Unsaturated fatty acid content in seston and tropho-dynamic coupling in lakes. Nature 427:69-71.

Nandini S, 2000. Responses of rotifers and cladocerans to Microcystis aeruginosa (Cyanophyceae): a demographic study. Aquat. Ecol. 34:227-242.

Nizan S, Dimentman C, Shilo M, 1986. Acute toxic effects of the cyanobacterium Microcystis aeruginosa on Daphnia magna. Limnol. Oceanogr. 31:497-502.

Oberhaus L, Gélinas M, Pinel-Alloul B, Ghadouani A, Humbert J-F, 2007. Grazing of two toxic Planktothrix species by Daphnia pulicaria: potential for bloom control and transfer of microcystins. J. Plankton Res. 29:827-838.

Ortiz-Rodríguez R, Wiegand C, 2010. Age related acute effects of microcystin-LR on Daphnia magna bitransformation and oxidative stress. Toxicon 56:1342-1349.

Pan M, Cederbaum AI, Zhang Y-L, Ginsberg HN, Williams KJ, Fisher EA, 2004. Lipid peroxidation and oxidant stress regulate hepatic apolipoprotein B degradation and VLDL production. J. Clin. Invest. 113:1277-1287.

Pflugmacher S, Wiegand C, Beattie KA, Krause E, Steinberg CEW, Codd GA, 2001. Uptake, effects, and metabolism of cyanobacterial toxins in the emergent reed plant Phragmites australis (Cav.) trin. ex steud. Environ. Toxicol. Chem. 20:846-852.

Pflugmacher S, Wiegand C, Oberemm A, Beattie KA, Krause E, Codd GA, Steinberg CEW, 1998. Identification of an enzymatically formed glutathione conjugate of the cyanobacterial hepatotoxin microcystin-LR: the first step of detoxication. Biochim. Biophys. Acta 1425:527-533.

Provincial Inspectorate for Environmental Protection, 2010. Reports of Lake Monitoring from 2007-2009. Provincial Inspectorate for Environmental Protection Publ., Warsaw. Available from: www.wios.warszawa.pl

Repka S. 1998. Effects of food type on the life history of Daphnia clones from lakes differing in trophic state. II. Daphnia cucullata feeding on mixed diets. Freshwater Biol. 38:685-692.

Rice-Evans CA, Diplock AT, Symons MCR, 1991. Techniques in free radicals research, p. 147-149. In: R.H. Burdon, P.H. van Knippenberg (eds.), Laboratory techniques in biochemistry and molecular biology. Elsevier, Amsterdam.

Richardson TL, Lawrenz E, Pinckney JL, Guajardo RC, Walker EA, Paerl HW, MacIntyre HL, 2010. Spectral fluorometric characterization of phytoplankton community composition using the Algae Online Analyser. Water Res. 44:2461-2472.

Rikans LE, Hornbrook KR, 1997. Lipid peroxidation, antioxidant protection and aging. Biochim. Biophys. Acta 1362:116-127.

Rohrlack T, Dittman E, Henning M, Börner T, Kohl J-G, 1999. Role of microcystins in poisoning and food ingestion inhibition of Daphnia galeata caused by the cyanobacterium Microcystis aeruginosa. Appl. Environ. Microb. 65:737-739.

Sarnelle O, Wilson AE, 2005. Local adaptation of Daphnia pulicaria to toxic cyanobacteria. Limnol. Oceanogr. 50:15651570 . 
Schwarzenberger A, Zitt A, Kroth P, Mueller S, Von Elert E, 2010. Gene expression and activity of digestive proteases in Daphnia: effects of cyanobacterial protease inhibitors. BMC Physiol. 10:6-20.

Senft AP, Dalton TP, Shertzer HG, 2000. Determining glutatione and glutatione disulfide using the fluorescence probe o-phthalaldehyde. Anal. Biochem. 280:80-86.

Smith JL, Boyer GL, Zimba PV, 2008. A review of cyanobacterial odorous and bioactive metabolitem: Impacts and management alternatives in aquaculture. Aquaculture 280:5-20.

Stangenberg M, 1968. Toxic effects of Microcystis aeruginosa Kutz. extracts on Daphnia longispina 0. F. Müller and Eucypris virens Jurinc. Hydrobiologia 32 :81-87.

Starmach K, 1966. [Cyanophyta - Sinice. Flora słodkowodna Polski. 2]. [in Polish]. Polish Scientific Publishers PWN, Warsaw.

Stillman JH, Colbourne JK, Lee CE, Patel NH, Phillips MR, Towle DW, Henry RP, Johnson EA, Pfrender ME, Terwilliger NB, 2008. Recent advances in crustacean genomics. Integr. Comp. Biol. 48:852-868.

Stocks R, Dormandy TL, 1971. The autooxidation of human red cell lipids induced by hydrogen peroxide. Brit. J. Haematol. 20:95-111.

Tarczyńska M, Romanowska-Duda Z, Jurczak T, Zalewski M, 2001. Toxic cyanobacterial blooms in drinking water reservoir - causes, consequences and management strategy. Wa. Sci. Technol. 1:237-246.
Thostrup L, Christoffersen K, 1999. Accumulation of microcystin in Daphnia magna feeding on toxic Microcystis. Arch. Hydrobiol. 145:447-467.

Tillmanns AR, Wilson AE, Pick FR, Sarnelle O, 2008. Metaanalysis of cyanobacterial effects on zooplankton population growth rate: species-specific responses. Fund. Appl. Limnol. 171:285-295.

Wagner I, Izydorczyk K, Kiedrzynska E, Mankiewicz-Boczek J, Jurczak T, Bednarek A, Wojtal-Frankiewicz A, Frankiewicz P, Ratajski S, Kaczkowski Z, Zalewski M, 2009. Ecohydrological system solution for enhancement of ecosystem services: the Pilica river demonstration project. Ecohydrol. Hydrobiol. 9:13-39.

Wiegand C, Pflugmacher S, 2005. Ecotoxicological effects of selected cyanobacterial secondary metabolites a short review. Toxicol. Appl. Pharm. 203:201-218.

Wilson AE, Sarnelle O, Tillmanns AR, 2006. Effects of cyanobacterial toxicity and morphology on the population growth of freshwater zooplankton: meta-analyses of laboratory experiments. Limnol. Oceanogr. 51:1915-1924.

Xie LQ, Xie P, Ozawa K, Honma T, Yokoyama A, Park HD, 2004. Dynamics of microcystins-LR and -RR in the phytoplanktivorous silver carp in a sub-chronic toxicity experiment. Environ. Pollut. 127:431-439. 